\title{
Great Moderation at the Firm Level? Unconditional vs. Conditional Output Volatility
}

\author{
CLAUDIA M. BUCH \\ JÖRG DÖPKE \\ KERSTIN STAHN
}

\author{
CESIFO WORKING PAPER NO. 2324 \\ CATEGORY 10: EMPIRICAL AND THEORETICAL METHODS \\ JUNE 2008
}
An electronic version of the paper may be downloaded
- from the SSRN website: Www.SSRN.com
- from the RePEc website: Www.RePEc.org
- from the CESifo website: www.CESifo-group.org/wp




\title{
Great Moderation at the Firm Level? Unconditional vs. Conditional Output Volatility
}

\begin{abstract}
Aggregated output in industrialized countries has become less volatile over the past decades. Whether this "Great Moderation" can be found in firm level data as well remains disputed. We study the evolution of firm level output volatility using a balanced panel dataset on German firms that covers 35 years (1971-2005) and about 1,500 firms per year. In contrast to earlier work using firm level data, we use the multifactor residual model proposed by Pesaran (2006) to isolate the idiosyncratic component of firms' real sales growth from macroeconomic developments. Our paper has three main findings. First, time trends in unconditional firm level and aggregated output volatility in Germany are similar. There has been a long-run downward trend, which was interrupted by the unification period. Second, the conditional, idiosyncratic firm level volatility does not exhibit a downward trend. If anything idiosyncratic volatility has been on a slow trend rise. Third, we find evidence of a positive link between growth and volatility at the firm level.
\end{abstract}

JEL Code: E32, D21.

Keywords: firm level volatility, Great Moderation, multifactor residual model.

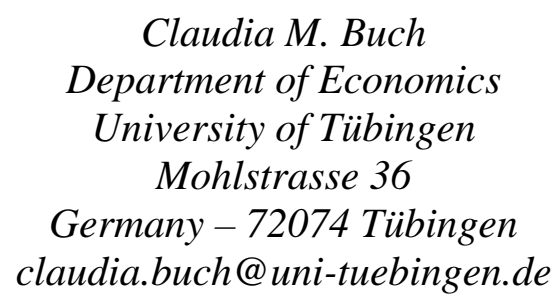

\author{
Jörg Döpke \\ University of Applied Sciences \\ Germany - Merseburg
}

\author{
Kerstin Stahn \\ Deutsche Bundesbank \\ Germany - Frankfurt
}

May 2008

The authors thank the Statistics Department of the Deutsche Bundesbank and, in particular, Timm Körting, for excellent data assistance and discussions on the data. We would also like to thank Jörg Breitung, Heinz Herrmann, Thomas Phillipon as well as seminar participants at the University of Osnabrück and at the Annual Meeting of the Council for Monetary Economics of the German Economic Association, held at the Austrian National Bank in February 2008, for most helpful discussions and comments. The views presented in this paper are those of the authors and do not necessarily reflect the opinions of the Deutsche Bundesbank. All errors and inconsistencies are solely our own responsibility. 


\section{Introduction}

Aggregated output has become less volatile over the past decades in industrialized countries (see, among others, Blanchard and Simon 2001, Stock and Watson 2003). While this stylized fact is widely accepted, the causes for the "Great Moderation" are still the subject of lively debate. The jury is still out on the question whether "Good Policy”, in particular a more stabilizing monetary policy, or "Good Luck", i.e. the absence of major shocks, is the main cause of the Great Moderation. (For recent contributions, see Benati 2007, Benati and Surico 2006, Canova 2006, or Giannone et al. 2007.)

Yet, for individual households, it is the development of volatility at the firm level rather than the development of aggregate volatility that matters. If firm level volatility increases, households must find ways to diversify firm level risks and to shield their consumption against income fluctuation. Possibilities for diversification, in turn, depend on the relative importance of macroeconomic and idiosyncratic factors affecting volatility at the firm level. Idiosyncratic volatility can be diversified in developed financial markets. Macroeconomic factors, in contrast, affect all firms in a similar manner and can be diversified nationally only to the extent that some firms react differently to the same macroeconomic shock. In this paper, we thus test whether evidence of a Great Moderation can be found at the firm level.

To date, there is little consensus reached how firm level output volatility has evolved over time, let alone the causes for changes in this volatility. For the USA, Comin and Philippon (2005) were the first to claim diverging patterns in firm level and aggregated output volatility. According to their results, firm level output volatility has increased, whereas aggregated output volatility has decreased (see also Comin and Mulani 2006). Comin et al. (2006) confirm these general patterns in the data and show that output and employment volatility display similar trends. Yet Davis et al. (2006) demonstrate that the finding of an increase in firm level output volatility crucially depends on the sample of firms chosen. According to their results, the increase in firm level volatility is a feature of large, publicly traded firms. Using information on privately-owned firms as well, Davis et al. (2006) find a downward trend in firm level volatility for the US, mirroring the macro level development. 
Evidence on firm level volatility for non-US countries is scarce (Davis and Kahn 2007). For France, Thesmar and Thoenig (2004) show an upward trend in firm level volatility. For Germany, patterns at the firm level are similar to those found in aggregated data, and there is no evidence of an increase in volatility (Buch et al. 2006). ${ }^{1}$

In this paper, we go beyond earlier studies by using a comprehensive panel dataset for German firms. These data allow tracking individual firms for a maximum of 35 years (1971-2005). Our data come from the Financial Statements Data Pool and the Corporate Balance Sheet Statistics of German firms provided by the Deutsche Bundesbank.

Methodologically, we depart from earlier literature in two regards. First, we use the multifactor residual model proposed by Pesaran (2006) to isolate the idiosyncratic growth of firms' sales from macroeconomic factors. We control for observed and unobserved macroeconomic developments affecting all firms while allowing for a heterogeneous response of firms to these factors. Our results show that differences between the unconditional volatility of firms' sales growth and the idiosyncratic, conditional volatility are quite substantial. Without distinguishing the micro- and the macro-component, inference about trends in firm level versus aggregate volatility might thus be misleading. Second, we employ fixed effects panel regressions as well as the heteroskedastic regression model proposed by Harvey (1976) to analyze the determinants of firm level growth volatility. This method has the advantage that we can simultaneously estimate the determinants of the mean and the variance of firms' sales growth. Moreover, our results do not rely on arbitrary choices of choosing a time window for the computation of (rolling) volatilities.

Why would one expect firm level and aggregated volatility to differ? After all, aggregate growth rates of GDP can be seen as the averaged growth rates across all firms in an economy. Yet, this does not automatically imply that the same trends as in the volatility of GDP growth can be found in firm level data. Instead, developments of growth volatility at the aggregate level and the firm level might differ if output changes are imperfectly correlated across firms (Comin and Phillipon 2005). Patterns of correlation, in turn, may change due to differences in the process of deregulation across

1 For evidence on aggregated volatility in Germany see Aßmann et al. (2006) and Buch et al. (2004). 
sectors, differences in $R \& D$ intensities, or different degrees of goods market competition. Also, advancing financial markets provide better opportunities for risksharing, which increases the ability of investors to take on risks. Depending on the degree of information asymmetries at the firm level, different firms might be affected differently. These arguments suggest that studying the development of aggregated volatility only may mask diverging trends at the firm level.

Davis et al. (2006), in contrast, argue that differences in the time series patterns of firm level and aggregated volatility are unlikely. They argue that volatility at different level of aggregation moves into the same direction if the shares of firms in aggregated output and the responses of firms to macroeconomic developments remain relatively stable.

The structure of the paper is as follows. In Part 2, we provide a brief theoretical background. In Parts 3 and 4, we describe our data and our empirical model. In Part 5, we use this model to decompose firms' growth rates into the idiosyncratic component and the component driven by macroeconomic factors, and we analyze the determinants of firm level growth volatility. Part 6 concludes. We find that trends in firm level and aggregate volatility are similar when looking at the unconditional volatility at the firm level. This supports the view of Davis et al. (2006). Controlling for macroeconomic developments, we find that firm level volatility is not only lower but also exhibits no downward trend. In fact, there even is some evidence of a very slow increase in idiosyncratic firm level volatility, supporting the view of Comin and Phillipon (2005). We also investigate the determinants of idiosyncratic volatility and find higher asset growth and lower inventory-sales ratios to be associated with a higher volatility of firms’ sales. Leverage has no significant impact.

\section{Theoretical Background}

In order to understand how firm level and aggregate volatility develop - and why time trends might differ - a theoretical framework which departs from the assumption of symmetric, homogenous firms is required. Using a standard Dixit-Stiglitz-type specification of household preferences, it can be shown that firm level prices and output depend on firm level and macroeconomic factors alike. As shown in Woodford (2003: 
Chapter 3), the first-order condition for the optimal pricing strategy of the supplier of good $i$ is then given by:

$$
\Pi_{1}\left(p_{t}(i), p_{t}^{I}, P_{t} ; Y_{t}, \xi_{t}, \xi_{i t}\right)=0
$$

where $\Pi_{1}$ is the first derivative of the firm i's profit function, $p_{t}(i)$ is the price charged for good i, $p_{t}^{I}$ is an index of the price charged in industry $I$ to which firm $i$ belongs, $P_{t}$ is the economy-wide price index, $Y_{t}$ is an index of aggregate demand, $\xi_{t}$ is a vector of exogenous macroeconomic disturbances, and $\xi_{i t}$ is a vector of firm-specific disturbances. According to equation (1), a firm's profit maximum with the corresponding prices and quantities depends on firm-specific, industry-specific, and macroeconomic developments. These variables, by definition, also have an impact on the volatility of firm level variables.

Equation (1) also implies that trends in the volatility of firm-specific and macroeconomic factors might differ if $\xi_{t}$ and $\xi_{i t}$ exhibit different time trends or if the propagation channels between micro- and macroeconomic developments change systematically over time. Focusing on the micro-economic determinants of firm level volatility, we can think of four main reasons why volatility may change over time.

First, the process of financial market deregulation and integration may provide better risk-sharing possibilities for investors. Hence, ceteris paribus, more risky firms may be able to obtain external finance, thus raising the average risk and volatility of firms. Thesmar and Thoenig (2004) find evidence for France supporting the hypothesis that the financial market deregulation has contributed to an increase in firm level output volatility. We will account for the importance of financial frictions by including the leverage ratio of firms.

Second, greater exposure to international competition and the deregulation of product markets may increase the elasticity of demand that firms are facing. This could change the responsiveness of firms to a given shock. ${ }^{2}$

2 See Rodrik (1997) for a related argument as to why labor market volatility may increase in integrated markets. 
Third, changes in the process of productivity growth away from the imitation of existing technologies towards innovative research and development may increase volatility. Eichengreen (2007), for instance, notes that, up until roughly the 1970s, growth in Europe was characterized by a catching up process to the technological frontier whereas in later decades innovative R\&D started to dominate.

Fourth, new information technologies have helped firms to improve their inventory management. During the "Great Moderation”, output volatility fell further than final sales volatility (Davis and Kahn 2007). This implies a change in the behavior of inventories in terms of lower volatility of inventories and/or a change in the covariance between inventories and sales. In our empirical analysis below, we will look at the volatility of real sales rather than output. From a theoretical point of view, we would expect inventories to be used to smoothen production when shocks to firms' sales dominate (Hornstein 1998). If productivity shocks dominate, in contrast, inventories are used to stabilize sales. Hence, we use firm level information on the inventory-sales ratio to account for the fact that inventories should be adjusted counter-cyclically with regard to fluctuations in real sales.

Our data are not rich enough to study the importance of all of these factors. However, we will show trends in the data and model the determinants of volatility as closely as possible to the above hypotheses. Our focus is on isolating micro factors and macro factors contributing to changes in firm level volatility.

\section{Data and Descriptive Statistics}

\subsection{The Data}

To document long-run trends in firm level volatility, we exploit, for the first time, a new firm level dataset that links two datasets available at the Deutsche Bundesbank: the Corporate Balance Sheets Statistics (Unternehmensbilanzstatistik), which covers the period from 1971 to 1996, and the Financial Statements Data Pool (Jahresabschlussdatenpool), which starts in 1997. (For methodological changes, see Deutsche Bundesbank (2005, 2006).) Earlier research was restricted to either of these statistics. For example, the Corporate Balance Sheets Statistics were used to trace the dynamics of firms over the cycle (Döpke and Weber 2006). The Financial Statements 
Data Pool was used to exploit the cross-section dimensions to analyze the link between growth and volatility at the firm level (Buch and Döpke 2007, 2008).

The Financial Statements Data Pool replaces the Corporate Balance Sheets Statistics of the Deutsche Bundesbank, as the number of corporate annual financial statements being submitted to the Bundesbank declined after the launch of the European Monetary Union in 1999 and the subsequent discontinuation of the Bundesbank's rediscount business. It has been compiled in a joint project of the Bundesbank and a number of commercial banks and other financial institutions. The Financial Statements Data Pool is somewhat broader than the Corporate Balance Sheet Statistics. The firms represented about three-quarters of the gross value added of the non-financial business sector in Germany in 2003 (Deutsche Bundesbank 2005). Both data sets can be used for statistical purposes, but under strict confidentiality on the premises of the Bundesbank only. The data have been made anonymous, and only Bundesbank staff is allowed to work with the Financial Statements Data Pool.

The total time series dimension of our new, linked data set covers 35 years (19712005). The unit of observation is the individual firm. Generally, our dataset contains information on all balance sheet items and financial statements. Since we are interested in tracking the evolution of a large number of firms over a long time horizon, we retrieve information on firms' sales, assets, the legal form, the industry, and some key firm level control variables only. We use the following firm level variables:

o (Real) sales: Like Comin and Phillipon (2005) or Davis et al. (2006), we use real sales as a proxy for firm level output. For this variable, we have relatively few data losses owing to incomplete and inconsistent reporting. Developments of sales and output differ in that the inventory growth and sales growth are imperfectly correlated. We use sales in order to avoid a possible bias arising from the fact that we have only balance sheet data on inventories. Lacking information on firm level prices, we convert nominal variables into real variables by deflating each firm's sales with the industry-level price index obtained from the EU KLEMS database (see www.euklems.net) and taking the difference of the logarithm of real sales.

o Assets: Total assets of firms are used as a proxy for the size of firms. The advantage of this measure over size measures such as the stock of fixed assets, 
equity capital, or external debt, is that it is not influenced by differences in the financing structure or the asset structure of firms. Also, total assets are a stock measure of firm size, which is likely to fluctuate less over time than sales as a flow measure.

o Inventories: We include the inventory-sales ratio to capture possible effects of technological changes on the volatility of firms' sales. This also takes into account that sales are an imperfect proxy of output if inventories change.

o Leverage: We compute a measure of leverage as a firm's debt divided by total equity. Leverage could be one measure of credit market friction. From a theoretical point of view, we expect that more severe financial friction reduce growth and increase the volatility of investment (Aghion and Banerjee 2005). Accordingly, the expected sign of leverage would be negative. ${ }^{3}$

Our dataset contains information on about 80,000 firms per year for the 1971-2005 period. The unrestricted dataset has 2.8 million firm-year observations. The average duration in the panel is about 13 years per firm. Since our empirical method, which will be explained in more detail below, is partly based on time series regressions for each individual firm, we retain only those firms which are present in the dataset for the full period. This reduces the total number of firms contained in the sample to 1,464 firms or 56,807 firm-year observations.

Table 1 gives the distribution of the unrestricted sample (i.e. the unbalanced panel) by the number of firms and the volume of real sales by industry (Table 1a) and years (Table 1b). We also provide comparative evidence of the balanced panel.

--- Insert Table 1 about here. ---

One particularly interesting feature of our dataset is that it contains information on manufacturing and services firms. In terms of the volume of sales, services account for roughly $19 \%$ of sales in the balanced panel. The bulk of these sales (13\%) is in the wholesale trade sector. In the unbalanced panel, the largest sector is wholesale trade as well, accounting for about $24 \%$ of total in terms of sales. The share of the wholesale

3 Note that information on leverage is not available for a number of firms, which reduces the size of our sample from about 1,750 to 1,450 firms. However, the qualitative results that are reported in the following also hold for the larger panel. 
trade sector is even higher in terms of the number of firms (21\% in the unbalanced panel and 29\% in the balanced panel). These numbers are out of proportion to the importance of this sector for GDP since we refer to sales rather than to value added. None of the remaining sectors dominates as clearly. As regards the number of firms, the basic metals sector (11.6\%) ranks second, and machinery and equipment (10.7\%) ranks third. In terms of the volume of real sales, the largest sector is petroleum products (29.6\%), followed by transport equipment (15.7\%), and wholesale trade (12.7\%).

A comparison of the structure of the balanced panel and the unbalanced panel shows that firms from manufacturing sectors are overrepresented and services firms are underrepresented in the balanced panel. This is not surprising since the balanced panel favors firms which had taken part in the Bundesbank's rediscount business. At the same time, this makes our findings robust to structural changes (see, e.g., Parker 2007). The disadvantage, of course, is that the inflow of younger and presumably riskier firms into the sample as well as the exit of high volatility firms is not captured. In Section 5.3 below, we discuss different sample splits, which take into account that the survivorship bias might differ across firms of different sectors, size, or legal status. Table $1 \mathrm{~b}$ shows the allocation of firms over the years. Here, the selection bias due to our restriction on a balanced panel is less severe, as we have about $3 \%$ of all observations in each year in both samples.

\subsection{Computing Firm Level Volatility}

As a first step towards computing firm level volatility, we compute firms' growth rates as

$$
g_{i t}=\frac{y_{i t}-y_{i t-1}}{y_{i t-1}}
$$

where $g_{i t}$ is firm $i$ 's sales growth rate, and $y_{i t}$ are firm $i$ 's real sales in $t$. Since our data contain no information on reasons for large outliers such as mergers and acquisitions, we drop observations which fall by more than half or more than double. Table 2a shows the descriptive statistics. The mean firm level growth rate for the full sample is 3.6\%, which is slightly higher than the growth rate of real GDP (2.2\%). 
As regards the measurement of volatility, it has become relatively standard in the literature to compute growth volatility as the standard deviation in growth rates over a moving 5-year or 10-year window (see, e.g., Comin and Phillipon 2006, Davis et al. 2006). The volatility of real sales over a 10 -year window is thus defined as:

$$
\sigma_{i t}^{10}(y)=\left[\frac{1}{10} \sum_{\tau=-9}^{0}\left(g_{i, t+\tau}-\bar{g}_{i t}\right)^{2}\right]^{1 / 2}
$$

where $\bar{g}_{i t}$ measures the mean growth rate. Correspondingly, the volatility over a 5year window $\sigma_{i t}^{5}(y)$ uses observations ranging from $t=-4$ to $t=0$.

Graph 1 plots the mean, unconditional firm level volatility of sales growth against the volatility of the growth rate of GDP. The unconditional volatility has not been corrected for macroeconomic influences. The median standard deviation of firm level growth is about $12 \%$, which is comparable to evidence found in earlier studies (Buch et al. 2006, Comin and Phillipon 2005) and 10 times higher than the volatility of aggregated GDP. Graph 1 shows that the time trends are quite similar and share two main features. First, there has been a trend decline in volatility over time. Second, volatility was temporarily higher in the period following German unification in the early 1990s. These general patterns in the data are very similar when using the unbalanced panel of firms.

--- Insert Graph 1 about here. ---

The information in Graph 1 alone, however, says little about time trends in the idiosyncratic volatility of firms' growth volatility though. We will therefore describe the methodology, in the following, how we isolate microeconomic factors from macroeconomic factors affecting firm level volatility.

\section{Computing Idiosyncratic Firm Level Volatility}

Previous empirical work on the determinants of firm level volatility uses the volatility of output as given by equation (3) as the dependent variable. Such regressions suffer from three potential problems. First, by construction, the dependent variable is serially correlated. Second, the choice of the 5-year or 10-year window for the 
computation of volatility is somewhat arbitrary, although it is often used in the empirical literature. Third, using the unconditional firm level volatility does not allow distinguishing idiosyncratic, firm level, from macroeconomic factors. The parallel evolution of firm level and aggregated volatility documented in Graph 1 could be the result of similar developments at different levels of aggregation, but it could also cloud diverging patterns at the firm level. Simply including observable macroeconomic volatilities as regressors may not fully isolate the idiosyncratic component because only observed factors are included. Also, in a pooled regression, the impact of macroeconomic factors is assumed to be homogenous across firms.

Hence, in this section, we describe the multifactor residual model recently proposed by Pesaran (2006). This model allows us to filter observed and unobserved macroeconomic factors out of the firm level data. It provides us with a measure of the conditional, idiosyncratic firm level real sales growth. To see the logic of the multifactor residual model, assume that firm level sales growth is given by

$$
g_{i t}=\alpha_{i}^{\prime} d_{t}+\beta^{\prime}{ }_{i} x_{i t}+\varepsilon_{i t}
$$

where $i=1,2, \ldots, N$ is the number of firms and $t=1,2, \ldots, T$ the number of years. $\alpha$ and $\beta$ are parameters to be estimated. Equation (4) states that firm level growth depends on a $k \times 1$ vector of observable macroeconomic factors $\left(d_{t}\right)$ and a vector of observed firm-specific regressors $\left(x_{i t}\right)$. The errors are assumed to have a multifactor structure:

$$
\varepsilon_{i t}=\gamma_{i}^{\prime} f_{t}+u_{i t}
$$

where $f_{t}$ is an $m \times 1$ vector of unobserved macroeconomic factors and $u_{i t}$ the individual-specific (idiosyncratic) errors, which are assumed to be distributed independently of $d_{t}$ and $x_{i t}$. In Pesaran (2006), the observed and unobserved factors $d_{t}$ and $f_{t}$ are assumed to be covariance stationary. Generally, the unobserved factors can be correlated with $\left(d_{t}, x_{i t}\right)$; the individual-specific regressors are modelled according to:

$$
x_{i t}=A_{i}^{\prime} d_{t}+\Gamma_{i}^{\prime} f_{t}+v_{i t}
$$


where $A_{i}$ and $\Gamma_{i}$ are factor loading matrices and $v_{i t}$ those components of $x_{i t}$ which are independent of the macroeconomic factors.

In most applications, the interest is in the slope coefficients $\beta_{i}$ in equation (4). The factor loadings $\alpha_{i}$ and $\gamma_{i}$ are not the main interest, but they can be estimated consistently when both $N$ and $T$ are large. Since our panel has a time series dimension of $T=35$, we can analyze the firm level responses to the macroeconomic factors. However, our main interest is in the variance of the idiosyncratic term $u_{i t}$. With an estimate of $u_{i t}$ at hand, we can compute the variance of the idiosyncratic component of firm level growth for each firm $i$. This variance can be proxied through the variance of the first-stage residuals: $\frac{1}{T+1} \sum_{j=0}^{T} \hat{u}_{i t-T+j}^{2} \forall i$, which converges to $\frac{1}{T+1} \sum_{j=1}^{T} \sigma\left(u_{i t-T+j}\right)^{2}$. (See e.g. Gorbachev (2007) for a similar specification using household consumption data.)

The key challenge is to isolate developments at the firm level from aggregate developments while taking into account the fact that some of the macroeconomic factors affecting all firms alike are unobserved. Hence, we isolate factors which affect all firms $\left(d_{t}, f_{t}\right)$ from those firm-specific variables, which are independent from the macroeconomic factors, i.e. the residual of equation (6) $\left(v_{i t}\right)$. We perform this decomposition in two steps.

In a first step, we run time-series regressions for sales growth of each firm in the sample on observed and unobserved macroeconomic factors. Following Pesaran (2006), the unobserved macroeconomic factors can be proxied through the sample means of firm-specific variables. We therefore take advantage of the fact that the model described by equations (4)-(6) is quite general as it allows the unobserved common factors $f_{t}$ to be correlated with the individual-specific regressors $x_{i t}$ via a multifactor structure with heterogeneous factor loadings over the cross-section units. We run these regressions for each of the firms in our balanced panel and for each of the firm level variables separately and retain the residuals from these regressions. The individual-specific coefficients are asymptotically unbiased as $N \rightarrow \infty$ for both $T$ fixed and $T \rightarrow \infty$ as long as the rank condition concerning the factor loadings is satisfied (Pesaran 2006). 
In a second step, we use the squared residuals from these time series regressions, which are the growth rates of firm level variables cleaned of the observed and unobserved factors, in a pooled firm level panel regression:

$$
u_{i t}^{2}=\alpha_{0}+\alpha_{1}^{\prime} v_{i t}+\alpha_{2}^{\prime} \delta_{i}+\alpha^{\prime}{ }_{3} \delta_{t}+\alpha^{\prime}{ }_{4} \delta_{s}+\alpha^{\prime}{ }_{5} \delta_{l}+\eta_{i t}
$$

where $u_{i t}^{2}$ is the squared residual of the first-stage regression of sales growth on macroeconomic factors, $\delta_{i}, \delta_{t}, \delta_{s}, \delta_{l}$ are firm-, time-, sector-, and legal fixed effects, and $v_{i t}$ is a set of firm-specific regressors, i.e. the first-stage residuals from equation (6). We use time fixed effects as a general specification of the time trend as well as a linear time trend. Note that the time trend also captures the fact that firm level volatility is related to firm age. Typically, older and more established firms are less volatile than younger firms. Taken in isolation, this should lead to a negative impact of the time trend on volatility but, of course, the trend also captures other factors that vary systematically over time.

To check whether there is a time trend in the variance of the idiosyncratic, conditional firm level growth rates, we also use graphical as well as regression-based evidence. We employ equation (3) above and compute the rolling standard deviation of the idiosyncratic volatility. In addition, we use fixed effects panel regressions and the heteroskedastic regression model suggested by Harvey (1976) to check whether the squared residuals as a proxy for the idiosyncratic volatility of firm level sales growth follow a systematic process. Note that the first-stage regressions account for the observed and unobserved macroeconomic factors in the mean growth of firm level sales. This does not preclude finding that macroeconomic factors and time trends to have an impact on the idiosyncratic variance of firm level growth.

\section{Decomposing and Explaining Firm Level Volatility}

Results for the unconditional volatility of firm level sales growth reported in Graph 1 provide evidence of a decline in firm level volatility, which largely resembles the drop in macroeconomic volatility. To what extent does this decline in firm level volatility result from lower volatility at the macro-level and to what extent does it reflect smaller 
idiosyncratic volatility? In this section, we report the results of the first- and secondstage regressions described above.

\subsection{First-Stage Regression: Decomposing Firm Level Volatility}

The goal of the first-stage regressions is to clean the growth of firm level variables of observed and unobserved macroeconomic factors. Our set of observed macroeconomic factors includes domestic and foreign as well as price and quantity measures. To capture the domestic macroeconomic environment, we include the growth rate of domestic absorption, short-term interest rates, and domestic inflation. To capture the international macroeconomic environment, we include the annual changes in the real exchange rate, world demand, and raw material prices. (Details on the data definitions are given in the Appendix.)

Table 2 reports the growth rate of other macroeconomic factors, i.e. domestic real absorption (1.8\%), world import volume (4.0\%), raw material prices (6.7\%), and the real effective exchange rate of the German economy against its 23 most important trading partners (-0.1\%). An increase in this indicator implies a real appreciation. The average short-term interest rate and the inflation rate over this period were $5.7 \%$ and $2.7 \%$, respectively.

--- Insert Table 2 about here. ---

We use four means of firm-specific variables as proxies for unobserved macroeconomic factors. The mean growth rate of firms' sales captures structural shifts in firm level growth. The growth rate of firms' assets captures changes in the size structure of firms. The mean inventory-sales ratio captures changes in the importance of inventories due to technological progress, and mean leverage across firms captures changing financial frictions. As expected, the inventory-sales ratio shows a downward trend over time, reflecting improvements in inventory management. Leverage, in contrast, has been increasing up until the early 1990s and falling thereafter, reflecting legislative changes affecting the financing of firms in Germany as well as the increase in stock market valuation during the 1990s.

Table $2 \mathrm{~b}$ shows the correlations between the observed macro-factors and the unobserved factors. All correlations are below 0.9, and most are below 0.5. We find the 
highest correlations between GDP growth and the growth rate of domestic absorption as well as between some firm level variables. Since domestic absorption is less correlated with the mean firm level factors than GDP growth, we use domestic absorption as our domestic demand component. In addition, the changes in the real exchange rate and in world imports as well as the interest rate and inflation show relatively high pairwise correlations. The same holds for the mean firm level variables. However, we include a full set of observed and unobserved macro-factors as these may still pick up some orthogonal component of the macroeconomic environment.

The advantage of running the first-stage regressions firm-by-firm is that we allow for the largest possible heterogeneity across firms. At the same time, results of these regressions are difficult to visualize. Therefore, we run simple cross-section regressions of the firm level responses to the macro-environment on a set of dummy variables. To account for the fact that the coefficients are measured with uncertainty, we weight these observations with the inverse of their standard deviation.

The aim of this exercise is to see whether, for instance, large and small firms react differently to the macroeconomic environment. Results reported in Table 3a show some differences in the response of firms to macroeconomic factors. Generally, larger firms grow faster than smaller firms when domestic and world market demand increases and the real exchange rate appreciates. Also, an increase in raw materials prices and in the real interest rate increases the growth of large firms relative to that of small firms. This would be consistent with large firms being oriented more towards the international market and less affected by financial constraints. Listed firms, in contrast, do not differ significantly from the rest of the sample. An increase in the real interest rate lowers growth of firms in the sectors manufacturing, services, and construction in comparison to growth in the remaining sectors (agriculture, mining, energy). Higher world import demand increases growth in the manufacturing and construction sector, while higher raw materials prices lower growth in manufacturing and services.

--- Insert Table 3 about here. ---

To assess the importance of the macroeconomic factors for firm level sales growth, we also compute the partial $R^{2} \mathrm{~s}$ for these factors. We compute the partial $R^{2} \mathrm{~s}$ by regressing firm level sales growth on all macroeconomic factors, excluding one, and by 
regressing the excluded factor on the remaining macroeconomic factors. Then, we regress the residual of the sales equation on the residual of the equation explaining the excluded factor, and we retain the $R^{2}$. This $R^{2}$ indicates how much a particular macroeconomic factor contributes to explaining the variance of firm level sales growth.

On average, the macroeconomic factors individually explain about $5-6 \%$ of the variance in sales growth across firms (Table 2c). However, the explanatory power varies widely with the highest partial $R^{2} \mathrm{~s}$ being in the range of 0.45 for domestic absorption and 0.59 for the real exchange rate. Hence, for some of the firms in the sample, individual macroeconomic factors explain more than $50 \%$ of the variance in real sales over time.

Table $3 \mathrm{~b}$ reports results of regressing the partial $R^{2} \mathrm{~s}$ on a set of dummy variables. Inflation has an above average explanatory power for large firms and for firms in manufacturing, services, and construction industries. World import demand has an above average explanatory power for manufacturing and services firms. Also, the construction sector differs from the rest of the sample in the sense that most macroeconomic factors (domestic absorption, the real exchange rate, and nominal interest rates) have a below-average explanatory power for firms from this sector.

Generally, the exact specification of the first-stage regressions should not be overemphasized. Essentially, these regressions serve the purpose of filtering macroeconomic information out of the firm level time series and to retain the idiosyncratic component of sales growth. In this sense, they are similar to the mean equations in an ARCH or GARCH setting, which serve the purpose of providing an estimate of the variance of the variable at hand.

The plots of the residual standard deviations are perhaps the most interesting outcome of these first-stage regressions. Graph 2 shows the conditional volatility of firms' sales growth. As before, we use a 5-year rolling window. There are two striking observations that immediately meet the eye.

--- Insert Graph 2 about here. ---

First, the conditional firm level volatility is lower than the unconditional volatility. During the turbulent 1970s, in particular, macroeconomic factors accounted for more than $50 \%$ of the volatility of firm level sales growth. In subsequent periods, the 
importance of macroeconomic factors has been less pronounced, but the gap between the conditional and the unconditional volatility series was still substantial. Hence, even though the impact of individual macroeconomic factors on firm level sales growth has, on average, been small, the overall impact of the macro-economy on firm level developments has been quite substantial.

Second, the downward trend in firm level volatility reported in Graph 1 is not visible once macroeconomic factors are taken into consideration. Instead, the time profile of firm level volatility is rather flat and even shows a slight upward trend. In this sense, our results confirm the conclusion reached by Davis et al. (2006) that (unconditional) firm level and aggregate volatility can be expected to behave similarly. However, our findings for the conditional volatility are also consistent with Comin and Phillipon (2006) who argue that the time trends of aggregate and firm level volatility differ.

\subsection{Second-Stage Regressions: Explaining the Volatility of Sales Growth}

Which are the firm-specific factors that determine the volatility of growth at the firm level? Do size and sector effects matter? Do we find support for different hypothesis as to the causes of the Great Moderation at the firm level? These are questions we will now turn to.

In Table 4, we report results of firm level regressions using the squared residuals of the first-stage regressions as a measure of the volatility of the conditional firm level growth rates of sales as a dependent variable (cf. equation (7)). We use fixed-effects panel regressions with robust standard errors. In contrast to the first-stage regressions, we now estimate homogenous coefficients.

--- Insert Table 4 about here. ---

Generally, our model explains less than $5 \%$ of the variation in the volatility of sales growth across firms. In similar (unreported) regressions using the growth rate of firms' sales as a dependent variable, we obtain higher $R^{2} \mathrm{~S}$ ranging from 0.13 to 0.19 . It does not come as a surprise to find that the explanatory power of the idiosyncratic, firm level volatility is relatively low, since we have stripped the variables off macroeconomic developments and since we consider only the idiosyncratic variation in the data. Moreover, these results are strongly driven by the very large amount of cross-sectional 
heterogeneity, which is typical for large micro-data sets like the one at hand. (Gorbachev (2007), for instance, analyzes the determinants of household-level consumption risk for the US and reports $R^{2} \mathrm{~s}$ in a similar range.)

We find a very consistent pattern of sales volatility to be positively related to growth of total assets. The estimated coefficient is about 0.03 , and it is quite robust across different specifications with regard to other control variables and the inclusion of fixed effects. Moreover, the impact of asset growth on firm level volatility builds up gradually over time. We include up to three lags of asset growth, and the first lag is significant throughout. In terms of economic significance, asset growth is the most important variable, with a beta coefficient of $8 \%$. Hence, variation in sales growth across firms accounts for about $8 \%$ in the variation of volatility across firms.

The finding that faster-growing firms also have more volatile sales growth is consistent with earlier findings at the firm level or industry level concerning the growthvolatility nexus. It is at odds with some findings for a negative relationship between growth and volatility using aggregated data. However, it would not come as a surprise to find that the growth rates of firms are imperfectly correlated. Imbs (2007), for example, shows that the correlation between growth and volatility depends on the level of aggregation of the data. He finds a positive correlation between growth and volatility at the industry level. One explanation is that growth rates are imperfectly correlated across sectors. Our firm level data suggest a similar positive relationship.

Firms with a high inventory-sales ratio have a low volatility of real sales. The beta coefficient is $-1.3 \%$. Leverage as a measure of the financial constraints that firms are facing is insignificant, in contrast. At first sight, the negative coefficient on inventories seems at odds with the hypothesis that improved inventory management helps firms to reduce the volatility of sales. According to this explanation, technological innovations help firms to reduce the desired inventory-sales ratio. A lower inventory-sales ratio, in turn, would weaken the destabilizing, pro-cyclical impact that inventories have for final sales via a positive covariance between inventories and sales (Ramey and Vine 2004). Our results would be consistent though with inventories serving as a buffer against productivity shocks. According to this interpretation, higher inventory-sales ratios would smoothen the impact of volatile production on sales. 
Generally, however, standard models of inventory management often fail to find support in the macro-data. Prominent theories such as the production smoothing model (Holt et al. 1960) predict a negative correlation between inventory investment and overall production, which was not found in the data. (See Blinder (1986) and the literature cited therein.) Rather, most macro studies find a positive correlation between inventory investment and GDP. Possible explanations of these findings point, inter alia, to the fact that inventories are still treated at a too aggregated level. In particular, a distinction between inventories of inputs and the inventories of finished goods is warranted. However, we lack such information in our dataset.

To test whether there are time trends in firm level volatility, we include a time trend and a unification dummy. The unification dummy and the time trend are insignificant if lagged dynamics are accounted for. This shows that our macroeconomic factors have filtered out impacts of the unification process on firm level volatility. The time trend is significant but relatively small, thus indicating only a relatively slow decline of volatility. Moreover, the beta coefficient is only $0.26 \%$. In contrast to unconditional firm level volatility and aggregated volatility, the idiosyncratic volatility of firms has thus been on a slow trend rise.

In unreported regressions, we include a full set of time-fixed effects as a more flexible way to capture time trends in the data. Results for the remaining control variables are unchanged. We also interact the time trend with a dummy variable for listed firms to test the hypothesis put forward by Davis et al. (2006) that firm level volatility has increased because of an upward trend in the volatility of large, publicly listed firms. However, this interaction term is insignificant.

\subsection{Robustness and Selection Issues}

To check the robustness of our results, we split the sample along different dimensions, we use a heteroskedastic regression model to simultaneously model the mean and the variance of idiosyncratic sales growth, and we correct for the bias arising from the fact that we estimate our model on a reduced sample of firms.

Sample splits: The descriptive statistics reported in Tables $1 \mathrm{a}$ and $1 \mathrm{~b}$ show differences between the full and the reduced sample. Hence, sample selection may affect our results since only firms which have data for the full sample are included. This 
sample selection could affect our results if the residuals from the regression of the determinants of firm level output volatility were correlated with residuals from a latent regression determining the survival of firms. These survival probabilities, in turn, may be related to firm size, the sector in which firms are active, or access to the capital market. To account for such differences, we split the sample into manufacturing and services, listed and unlisted, and small and large firms (Table 4a). The cut-off for small and large firms is the median level of real sales. To test whether time trends in firm level volatility have changed over time, we break down the sample further into the 1970s, the 1980s, the 1990s, and the current decade (Table 4b). We also split the sample in 1985, the year which is often taken as the start of the Great Moderation period.

Perhaps the most interesting finding is that the qualitative results for the control variables are generally not affected by the different sample compositions. There are a few exceptions though. In the 1970s, none of our control variables is significant. Instead, there has been a positive and significant upward time trend in firm level volatility. Moreover, the inventory-sales ratio is insignificant for the sub-samples of listed firms (although the negative sign is retained). Inventories have a negative and significant effect for services firms, which would seem surprising for services which are non-storable. However, since the sector "services" also includes retail and wholesale trade firms and since these firms carry inventories, this effect seems quite plausible.

Selection bias: In unreported regressions, we have also estimated the volatility regression applying the correction for sample selection proposed by Heckman (1976). The selection equation shows that large firms, firms with lower sales growth, and firms with lower leverage are more likely to be in the balanced panel. The Mills ratio is significant, indicating that sample selection is indeed an issue. Results for the equation explaining the volatility of firm level output show very similar results with regard to the coefficient estimates and significance as regressions not accounting for the selection bias. More specifically, firms that grow faster, that have a higher inventory sales ratio, and that have lower leverage have a lower volatility. The linear time trend is again positive and significant.

Heteroskedastic regression model: To check the robustness of our results for the variance equation, we alternatively use a regression model with multiplicative 
heteroskedasticity as proposed by Harvey (1976). The advantage of this model is that we can simultaneously specify a "mean” equation - explaining the growth of sales - as well as a "variance" equation - explaining the residual variance.

The heteroskedastic regression model has, to the best of our knowledge, not been applied to an analysis of firm level volatility so far. Earlier applications use it to model heteroskedasticity in the residuals, yet most papers do not focus on estimates of the variance equation. There are two exceptions. A recent paper by Cerqueiro et al. (2007) studies banks’ loan pricing decisions. Ang and Peterson (1985) estimate a capital asset pricing model and study the determinants of rates of returns as well as the variance of returns.

The mean equation of the heteroskedastic regression model gives the level of sales growth as a function of a set of explanatory variables $X: \tilde{g}_{i t}=\tilde{x}^{\prime}{ }_{i t} \beta+\varepsilon_{i t}$ where $\varepsilon_{i t}$ is the residual with $E\left[\varepsilon_{i t} \mid \tilde{x}_{i t}\right]=0$ and $\operatorname{VAR}\left[\varepsilon_{i t} \mid \tilde{x}_{i t}\right]=\sigma_{i t}^{2}=\exp \left\{Z^{\prime}{ }_{i j} \phi\right\}$. The variance equation is given by $\sigma_{i t}^{2}=Z^{\prime}{ }_{i t} \phi$. The coefficients $\beta$ and $\phi$ can be obtained by maximizing the log-likelihood function. One advantage of this methodology is that the parameters of the mean and of the variance equation are uncorrelated. We essentially estimate the same model as before but we now include dummies for the different types of firms (large versus small, listed versus unlisted) in lieu of a full set of firm fixed effects.

Results are reported in Table 5. Turning to the results of the mean equation first, we find that asset growth is positively correlated with the growth rate of firm level sales. There is evidence that larger firms grow faster than average. Large inventory-sales ratios are associated with lower sales growth, indicating that inventories contain mainly finished products. Since the specification of the mean equation is certainly a bit ad hoc, we also use a specification using a linear time trend and the unification dummy only.

--- Insert Table 5 about here. ---

The results for the variance equation by and large confirm the findings reported above considering the positive impact of higher asset growth and the positive impact of the time trend. The firm size dummy is negative and significant. The negative impact of 
the inventory-sales ratio is significant only in the specification using a very lean specification of the mean equation (Column 2 of Table 5).

\section{Summary and Conclusions}

This paper has tested whether evidence of a "Great Moderation" can be found in firm level data of German firms. To answer this question, we have used a unique firm level dataset which allows a large sample of German firms to be tracked across 35 years. Our paper has three main findings.

First, the unconditional firm level volatility and aggregate volatility have developed quite similarly. This confirms Davis et al. (2006) who use US data and differs from the findings of Comin and Phillipon (2005) who find diverging trends of firm level and aggregated volatility.

Second, we show that inference about the evolution of firm level volatility requires us to take account of macroeconomic factors. Using the multifactor panel model proposed by Pesaran (2006), we have decomposed firm level sales growth and volatility into the idiosyncratic component and the component driven by observed and unobserved macroeconomic developments. Results from this disaggregation show that the overall time trends in unconditional firm level volatility are driven by macroeconomic factors. Once we take this into account and extract the idiosyncratic component of firm level volatility, we not only find volatility to be lower but also to exhibit a flat and, if anything, slightly increasing pattern.

Third, we use different panel models to analyze the determinants of the idiosyncratic component of firm level volatility. Faster-growing firms also exhibit a higher volatility of real sales growth. In this sense, higher idiosyncratic volatility could have a positive impact on overall growth and thus economic welfare. If anything, the time trend in firm level volatility has been positive. However, the time trend explains only a very small share of the variation in idiosyncratic volatility across firms and time.

Our results show the importance of a stable macroeconomic environment for firm level stability. High macroeconomic volatility such as was observed during the 1970s has roughly doubled firm level volatility. In later periods, the decline in firm level volatility was driven largely by the decline in macroeconomic volatility. To the extent 
that "Good Policy" is behind the decline in aggregate volatility, this has also contributed to lower volatility at the firm level. Idiosyncratic, firm level volatility exhibits no particular time trend. Studying whether similar patterns can be found in other indicators such as the volatility employment, income, and consumption, remains an important topic for future research.

Finally, our paper has implications for the potential to diversify risks across German firms. Whereas a substantial part of volatility at the firm level is driven by common macroeconomic factors, which limits the diversification potential across domestic firms, the relative importance of idiosyncratic risks has increased over time. These risks, however, can be diversified in developed financial markets.

\section{References}

Aghion, P., and A. Banerjee (2005). Volatility and Growth. Oxford University Press. Oxford.

Ang, J.S., and D.R. Peterson (1985). Return, Risk, and Yield: Evidence from Ex Ante Data. Journal of Finance 40(2): 537-548.

Aßmann, C., J. Hogrefe, and R. Liesenfeld (2006). The Decline in German Output Volatility: A Baysian Analysis. Christian-Albrechts-Universität Kiel. Working Paper 2006-02. Kiel.

Benati, L. (2007). The “Great Moderation” in the United Kingdom. European Central Bank. Working Paper 769. Frankfurt a.M.

Benati, L., and P. Surico (2006). VAR Analysis and the Great Moderation: A Reply to Fabio Canova. Bank of England. Mimeo.

Blanchard, O.J. and Simon, J.A. (2001). The Long and Large Decline in U.S. Output Volatility. Brookings Papers on Economic Activity: 165-173.

Blinder, A. S. (1986). Can the Production Smoothing Model of Inventory Behaviour be Saved? Quarterly Journal of Economics: 431-453.

Buch, C.M., and J. Döpke (2007). Growth and Volatility: Firm level Evidence and the Impact of Openness. In: W. Franz, H. J. Ramser, and M. Stadler: Arbeitsverträge

Buch, C.M., and J. Döpke (2008). Growth, Volatility, and Credit Market Imperfections: Evidence from German Firms. Journal of Economic Studies (forthcoming) 
Buch, C.M., J. Döpke, and C. Pierdzioch (2004). Business Cycle Volatility in Germany. German Economic Review 5(4): 451-479.

Buch, C.M., J. Döpke, and H. Strotmann (2006). Does Export Openness Increase Firm level Volatility? Deutsche Bundesbank. Discussion Paper 40/2006. Frankfurt a.M.

Canova, F. (2006). You can use VAR for structural analyses. A comment to VARs and the Great Moderation. ICREA, Universitat Pompeu Fabra, CREI and CEPR. Mimeo.

Cerqueiro, G., H. Degryse, and S. Ongena (2007). Rules versus Discretion in Loan Rate Setting. CentER Tilburg University. Mimeo.

Comin, D., and S. Mulani (2006). Diverging Trends in Aggregate and Firm Volatility. Review of Economics and Statistics 88(2): 374-383.

Comin, D., and T. Philippon (2005). The rise in firm level volatility: causes and consequences. National Bureau of Economic Research. NBER Working Paper 11388. Cambridge MA.

Comin, D., E.L. Groshen, and B. Rabin (2006). Turbulent Firms, Turbulent Wages? National Bureau of Economic Research (NBER). Working Paper 12032. Cambridge, MA.

Davis, S.J., J. Haltiwanger, R. Jarmin, and J. Miranda (2006). Volatility and Dispersion in Business Growth Rates: Public Traded versus Privately Held Firms. National Bureau of Economic Research. NBER Working Paper 12354. Cambridge MA.

Davis, S.J., and J.A. Kahn (2007). Changes in the Volatility of Economic Activity at the Macro and Micro Levels. University of Chicago, Stern School, and NBER. Mimeo.

Deutsche Bundesbank (2005). German enterprises” profitability and financing - an analysis based on a new dataset. Deutsche Bundesbank Monthly Report. Frankfurt a.M.. October 2005: 31-67.

Deutsche Bundesbank (2006). Extrapolated results from financial statements of German enterprises 1994 to 2003. Deutsche Bundesbank Special Statistical Publication 5. Frankfut a. M. March 2006: 5-19.

Döpke, J. and S. Weber (2006), The within-distribution business cycle dynamics of German firms. Deutsche Bundesbank. Discussion Paper 29/2006. Frankurt a.M.

Eichengreen, B. (2007). The European Economy since 1945: Coordinated Capitalism and Beyond. Princeton University Press. 
Giannone, D., M. Lenza, and L. Reichlin (2007). Explaining The Great Moderation: It Is Not The Shocks. CEPR Discussion Paper 6600. London.

Gorbachev, O. (2007). Did Household Consumption Become More Volatile? Department of Economics, Columbia University. Mimeo.

Harvey, A. (1976). Estimating Regression Models with Multiplicative Heteroskedasticity. Econometrica 44: 461-465.

Heckman, J. (1976). The common structure of statistical models of truncation, sample selection, and limited dependent variables and a simple estimator for such models. Annals of Economic and Social Measurement 5: 475-492.

Holt, C. et al. (1960). Planning production, inventories, and workforce. Engelwood Cliffs.

Hornstein, A. (1998). Inventory Investment and the Business Cycle. Federal Reserve Bank of Richmond. Economic Quarterly 84/2: 49-71.

Imbs, J. (2007). Growth and Volatility. Journal of Monetary Economics 54 (2007) 1848-1862.

Parker, M. (2007). Diverging Trends in Aggregate and Firm-Level Volatility in the UK. Bank of England. External MPC Unit. Discussion Paper 16. London.

Pesaran, M.H. (2006). Estimation and Inference in Large Heterogeneous Panels with Multifactor Error Structure. Econometrica 74(4): 967-1012.

Rodrik, D. (1997). Has Globalization Gone Too Far? Institute for International Economics, Washington D.C. 51.

Stock, J.H., and M.W. Watson (2003). Has the Business Cycle Changed? Evidence and Explanations. Harvard University, Princeton University, and NBER. Mimeo

Thesmar, D., and M. Thoenig (2004). Financial Market Development and the Rise in Firm Level Uncertainty. ENSAE-CREST, CERAS-CNRS, and CEPR. Mimeo. 


\section{Data Appendix}

\section{Firm Level Data}

All firm level data are taken from the Corporate Balance Sheet Statistics and the Financial Statements Data Pool provided by the Deutsche Bundesbank (Deutsche Bundesbank 2005). The data are confidential firm level data, and the Financial Statements Data Pool can be used by the staff of the Deutsche Bundesbank only.

Asset growth: Annual growth of firm's total assets.

Inventory-sales-ratio: Ratio of a firm's inventory over total sales.

Large/small firms: Firms with real sales above (below) the sample median.

Leverage: Ratio of a firm's total debt to total equity.

Listed/unlisted firms: Incorporated (not incorporated) companies (Aktiengesellschaften).

Manufacturing firms: Chemicals, Basic metals, Machinery, Transport equipment, Electrical equipment, Wood, Pulp and paper, Textiles, Food, Computers, Non-metallic mineral products, Plastic products, Petroleum products, Furniture.

Services firms: Wholesale trade, Hotels, Transport \& communication, Financial intermediation, Real estate, Public services, Retail trade, Firm-related services.

\section{Macroeconomic Data and Sources}

GDP growth (\%): Annual growth rate of German real GDP (German Federal Statistical Office).

Growth rate of domestic absorption (\%): Annual growth rate of German real absorption (German Federal Statistical Office).

Growth rate of world imports (\%): Annual growth of world import volumes (International Monetary Fund).

Change in real exchange rate (\%): Annual growth of Germany"s real effective exchange rate against 23 countries in quantity notation. An increase indicates a real appreciation (European Central Bank).

Change in raw material prices (\%): Annual growth rate of the HWWA index of raw material prices (overall index).

Short-term interest rate (\%): Average short-term interest rate (3 months, Frankfurt money market rate; Deutsche Bundesbank). 


\section{Table 1: Distribution of Firms by Sector and Year}

This table gives the distribution of firms in the sample by sector (Table 1a) and year (Table 1b). We report the distribution of the number of firms and of the volume of real sales (in million euro). The balanced panel includes all firms; the unbalanced panel includes only firms which are in the sample for the full period.

Table 1a: Distribution of Firms by Sector

\begin{tabular}{|c|c|c|c|c|c|c|c|c|}
\hline & \multicolumn{4}{|c|}{ Number of firms } & \multicolumn{4}{|c|}{ Real sales } \\
\hline & \multicolumn{2}{|c|}{ Unbalanced } & \multicolumn{2}{|c|}{ Balanced } & \multicolumn{2}{|c|}{ Unbalanced } & \multicolumn{2}{|c|}{ Balanced } \\
\hline & Number & Percent & Number & Percent & Mil. euro & Percent & Mil. euro & Percent \\
\hline Agriculture & 75,905 & 2.66 & 70 & 0.14 & 136.96 & 0.2 & 5.21 & 0.04 \\
\hline Basic Metals & 162,012 & 5.67 & 5,922 & 11.56 & 3715.76 & 5.5 & 554.64 & 4.72 \\
\hline Chemicals & 32,498 & 1.14 & 2,119 & 4.14 & 3007.83 & 4.45 & 709.93 & 6.04 \\
\hline Computers & 4,315 & 0.15 & 24 & 0.05 & 467.71 & 0.69 & 7.72 & 0.07 \\
\hline Construction & 256,831 & 8.99 & 1,710 & 3.34 & 2257.61 & 3.34 & 176.54 & 1.5 \\
\hline Electrical equipment & 84,587 & 2.96 & 1,995 & 3.89 & 3339.02 & 4.94 & 530.11 & 4.51 \\
\hline Energy & 17,316 & 0.61 & 997 & 1.95 & 2805.73 & 4.15 & 389.37 & 3.31 \\
\hline Financial intermediation & 2,037 & 0.07 & n.a. & n.a. & 79.72 & 0.12 & n.a. & n.a. \\
\hline Firm related services & 141,704 & 4.96 & 126 & 0.25 & 1171.98 & 1.73 & 2.71 & 0.02 \\
\hline Food & 90,483 & 3.17 & 2,993 & 5.84 & 3416.93 & 5.06 & 307.85 & 2.62 \\
\hline Furniture & 28,801 & 1.01 & 633 & 1.24 & 306.31 & 0.45 & 20.42 & 0.17 \\
\hline Hotels & 19,952 & 0.7 & n.a. & n.a. & 84.67 & 0.13 & 0.00 & n.a. \\
\hline Machinery & 152,390 & 5.34 & 5,498 & 10.73 & 3846.20 & 5.69 & 473.37 & 4.03 \\
\hline Mining & 23,341 & 0.82 & 443 & 0.86 & 826.85 & 1.22 & 267.23 & 2.27 \\
\hline \multicolumn{9}{|l|}{ Non-metallic } \\
\hline mineral products & 48,739 & 1.71 & 1,712 & 3.34 & 783.03 & 1.16 & 147.25 & 1.25 \\
\hline Petroleum products & 1,728 & 0.06 & 209 & 0.41 & 6217.74 & 9.2 & 3479.59 & 29.6 \\
\hline Plastic products & 56,767 & 1.99 & 1,312 & 2.56 & 1080.94 & 1.6 & 186.90 & 1.59 \\
\hline Public services & 64,973 & 2.27 & 62 & 0.12 & 837.19 & 1.24 & 15.74 & 0.13 \\
\hline Pulp and paper & 72,340 & 2.53 & 1,844 & 3.6 & 1406.65 & 2.08 & 154.83 & 1.32 \\
\hline Real estate & 184,257 & 6.45 & 137 & 0.27 & 1187.24 & 1.76 & 4.69 & 0.04 \\
\hline Retail trade & 432,062 & 15.13 & 2,872 & 5.6 & 5688.73 & 8.42 & 571.69 & 4.86 \\
\hline Textiles & 92,461 & 3.24 & 3,238 & 6.32 & 1174.39 & 1.74 & 133.50 & 1.14 \\
\hline \multicolumn{9}{|l|}{ Transport } \\
\hline \& communication & 107,160 & 3.75 & 458 & 0.89 & 2302.19 & 3.41 & 239.76 & 2.04 \\
\hline Transport equipment & 22,795 & 0.8 & 862 & 1.68 & 4733.33 & 7.01 & 1848.69 & 15.73 \\
\hline Wholesale trade & 590,360 & 20.67 & 14,965 & 29.21 & 16031.16 & 23.73 & 1498.17 & 12.74 \\
\hline Wood & 78,183 & 2.74 & 1,019 & 1.99 & 656.98 & 0.97 & 30.29 & 0.26 \\
\hline Unallocated & 12,009 & 0.42 & 20 & 0.04 & & & & \\
\hline Total & $2,856,006$ & 100 & 51,240 & 100 & 67562.86 & 100 & 11756.18 & 100 \\
\hline
\end{tabular}


Table 1b: Distribution of Firms by Year

\begin{tabular}{|c|c|c|c|c|c|c|c|c|}
\hline \multirow[b]{3}{*}{ Year } & \multicolumn{4}{|c|}{ Number of firms } & \multicolumn{4}{|c|}{ Real sales } \\
\hline & \multicolumn{2}{|c|}{ Unbalanced } & \multicolumn{2}{|c|}{ Balanced } & \multicolumn{2}{|c|}{ Unbalanced } & \multicolumn{2}{|c|}{ Balanced } \\
\hline & Number & Percent & Number & Percent & Mil. euro & Percent & Mil. euro & Percent \\
\hline 1971 & 47,081 & 1.65 & 1,464 & 2.86 & 1126.02 & 1.67 & 237.63 & 2.02 \\
\hline 1972 & 47,649 & 1.67 & 1,464 & 2.86 & 1211.66 & 1.79 & 274.21 & 2.33 \\
\hline 1973 & 47,983 & 1.68 & 1,464 & 2.86 & 1235.05 & 1.83 & 236.49 & 2.01 \\
\hline 1974 & 50,057 & 1.75 & 1,464 & 2.86 & 1338.98 & 1.98 & 251.58 & 2.14 \\
\hline 1975 & 61,034 & 2.14 & 1,464 & 2.86 & 1389.46 & 2.06 & 275.13 & 2.34 \\
\hline 1976 & 70,758 & 2.48 & 1,464 & 2.86 & 1547.38 & 2.29 & 297.35 & 2.53 \\
\hline 1977 & 78,006 & 2.73 & 1,464 & 2.86 & 1643.88 & 2.43 & 345.54 & 2.94 \\
\hline 1978 & 84,658 & 2.96 & 1,464 & 2.86 & 1588.63 & 2.35 & 302.41 & 2.57 \\
\hline 1979 & 87,734 & 3.07 & 1,464 & 2.86 & 1694.85 & 2.51 & 313.94 & 2.67 \\
\hline 1980 & 83,461 & 2.92 & 1,464 & 2.86 & 1714.93 & 2.54 & 313.84 & 2.67 \\
\hline 1981 & 77,945 & 2.73 & 1,464 & 2.86 & 1809.99 & 2.68 & 347.65 & 2.96 \\
\hline 1982 & 78,270 & 2.74 & 1,464 & 2.86 & 1783.21 & 2.64 & 357.54 & 3.04 \\
\hline 1983 & 79,905 & 2.8 & 1,464 & 2.86 & 1775.05 & 2.63 & 350.66 & 2.98 \\
\hline 1984 & 80,632 & 2.82 & 1,464 & 2.86 & 1859.23 & 2.75 & 379.22 & 3.23 \\
\hline 1985 & 79,846 & 2.8 & 1,464 & 2.86 & 1866.91 & 2.76 & 378.69 & 3.22 \\
\hline 1986 & 79,273 & 2.78 & 1,464 & 2.86 & 1707.83 & 2.53 & 328.64 & 2.8 \\
\hline 1987 & 78,328 & 2.74 & 1,464 & 2.86 & 1819.53 & 2.69 & 423.13 & 3.6 \\
\hline 1988 & 76,000 & 2.66 & 1,464 & 2.86 & 1861.77 & 2.76 & 408.70 & 3.48 \\
\hline 1989 & 73,296 & 2.57 & 1,464 & 2.86 & 1947.44 & 2.88 & 467.55 & 3.98 \\
\hline 1990 & 71,734 & 2.51 & 1,464 & 2.86 & 2032.62 & 3.01 & 480.62 & 4.09 \\
\hline 1991 & 72,123 & 2.53 & 1,464 & 2.86 & 2112.71 & 3.13 & 461.08 & 3.92 \\
\hline 1992 & 71,819 & 2.51 & 1,464 & 2.86 & 1862.75 & 2.76 & 324.80 & 2.76 \\
\hline 1993 & 71,246 & 2.49 & 1,464 & 2.86 & 1715.33 & 2.54 & 283.22 & 2.41 \\
\hline 1994 & 71,651 & 2.51 & 1,464 & 2.86 & 1839.71 & 2.72 & 283.91 & 2.41 \\
\hline 1995 & 68,442 & 2.4 & 1,464 & 2.86 & 1887.40 & 2.79 & 278.82 & 2.37 \\
\hline 1996 & 66,430 & 2.33 & 1,464 & 2.86 & 1789.63 & 2.65 & 229.48 & 1.95 \\
\hline 1997 & 104,157 & 3.65 & 1,464 & 2.86 & 2329.22 & 3.45 & 333.35 & 2.84 \\
\hline 1998 & 97,194 & 3.4 & 1,464 & 2.86 & 2154.85 & 3.19 & 288.02 & 2.45 \\
\hline 1999 & 98,674 & 3.45 & 1,464 & 2.86 & 2297.06 & 3.4 & 301.90 & 2.57 \\
\hline 2000 & 100,916 & 3.53 & 1,464 & 2.86 & 2605.32 & 3.86 & 333.83 & 2.84 \\
\hline 2001 & 106,080 & 3.71 & 1,464 & 2.86 & 2761.53 & 4.09 & 345.94 & 2.94 \\
\hline 2002 & 111,348 & 3.9 & 1,464 & 2.86 & 2699.09 & 3.99 & 338.89 & 2.88 \\
\hline 2003 & 123,129 & 4.31 & 1,464 & 2.86 & 2735.96 & 4.05 & 351.22 & 2.99 \\
\hline 2004 & 134,397 & 4.71 & 1,464 & 2.86 & 2850.51 & 4.22 & 406.53 & 3.46 \\
\hline 2005 & 124,750 & 4.37 & 1,464 & 2.86 & 2967.38 & 4.39 & 424.69 & 3.61 \\
\hline Total & $2,856,007$ & 100 & 51,240 & 100 & 67562.86 & 100 & 11756.18 & 100 \\
\hline
\end{tabular}


Table 2: Descriptive Statistics and Correlation Matrix

This table reports descriptive statistics for the data used in the regressions.

\section{$\underline{\text { Table 2a: Descriptive Statistics }}$}

\begin{tabular}{|c|c|c|c|c|c|}
\hline Variable & Obs & Mean & Std. dev. & Min & Max \\
\hline GDP growth & 49,183 & 0.022 & 0.017 & -0.009 & 0.052 \\
\hline Growth rate of domestic absorption & 49,183 & 0.019 & 0.021 & -0.022 & 0.052 \\
\hline Growth rate of world imports & 49,183 & 0.040 & 0.113 & -0.211 & 0.305 \\
\hline Change in real exchange rate & 49,183 & -0.001 & 0.048 & -0.099 & 0.113 \\
\hline Change in raw material prices & 49,183 & 0.067 & 0.239 & -0.474 & 0.943 \\
\hline Short-term interest rate & 49,183 & 0.057 & 0.027 & 0.021 & 0.121 \\
\hline Inflation & 49,183 & 0.028 & 0.019 & -0.007 & 0.073 \\
\hline Mean firm level growth real sales & 49,183 & 0.036 & 0.043 & -0.067 & 0.157 \\
\hline Mean firm level growth of assets & 49,183 & 0.037 & 0.037 & -0.045 & 0.107 \\
\hline Mean inventory-sales ratio & 49,183 & 0.162 & 0.007 & 0.147 & 0.173 \\
\hline Mean leverage & 49,183 & 6.835 & 0.866 & 5.365 & 8.428 \\
\hline Growth rate of firm level real sales & 49,183 & 0.036 & 0.162 & -0.498 & 1.950 \\
\hline Growth rate of firm level assets & 49,183 & 0.037 & 0.172 & -0.499 & 1.892 \\
\hline Inventory-sales ratio & 49,183 & 0.162 & 0.147 & 0.000 & 7.970 \\
\hline Leverage & 49,183 & 6.836 & 9.663 & -0.052 & 99.931 \\
\hline Residual growth firm level real sales & 49,183 & 0.000 & 0.121 & -0.763 & 1.566 \\
\hline Residual growth firm level assets & 49,183 & 0.000 & 0.134 & -0.836 & 1.612 \\
\hline Residual inventory-sales ratio & 49,183 & 0.000 & 0.053 & -1.327 & 3.109 \\
\hline Residual leverage & 49,183 & 0.000 & 4.074 & -44.065 & 66.140 \\
\hline
\end{tabular}


Table 2b: Correlation Matrix

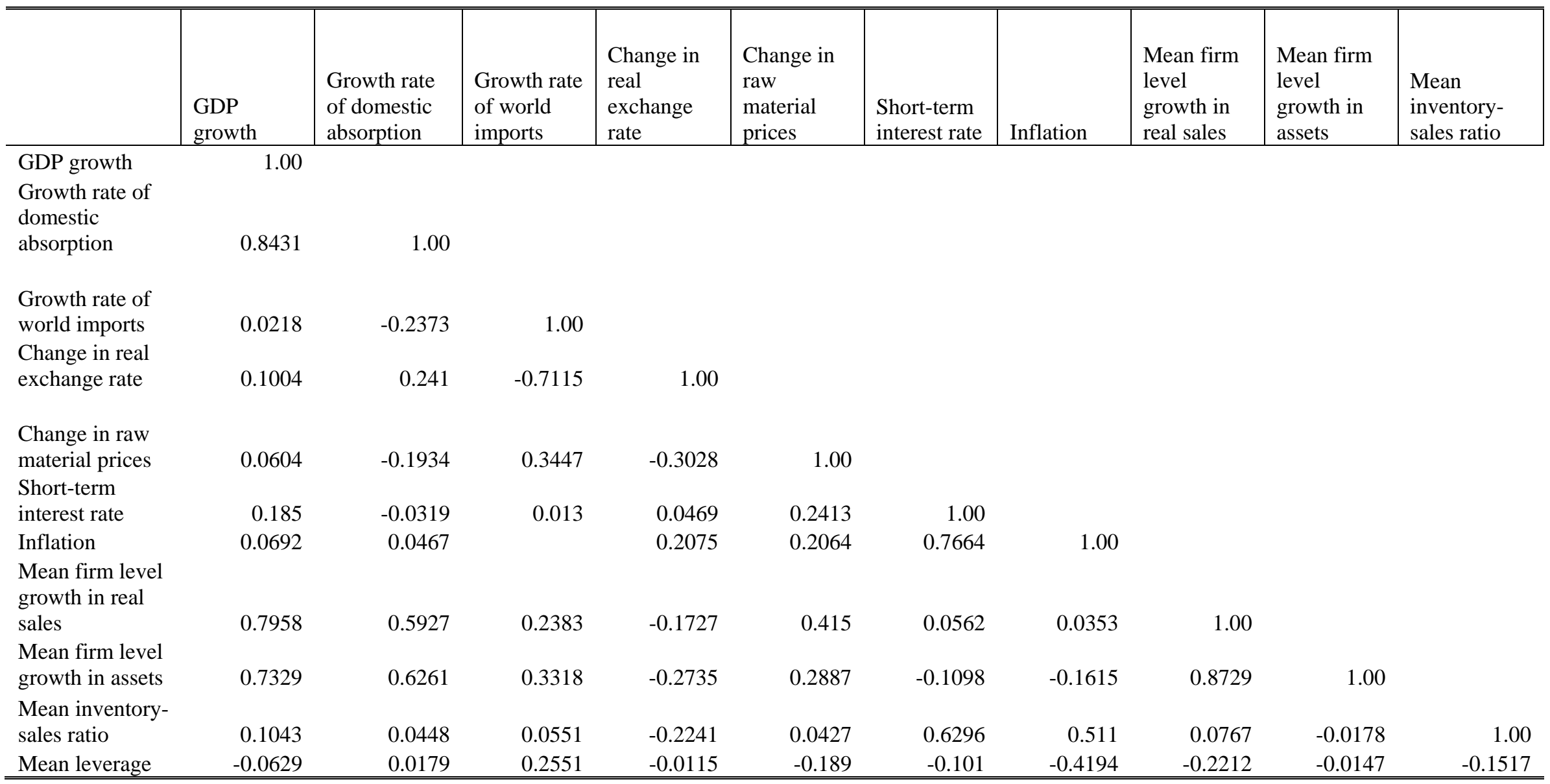


Table 2c: Descriptive Statistics: Partial $R^{2}$

\begin{tabular}{|c|c|c|c|c|c|}
\hline & Observations & Mean & $\begin{array}{l}\text { Standard } \\
\text { deviation }\end{array}$ & Minimum & Maximum \\
\hline $\begin{array}{l}\text { Domestic } \\
\text { absorption }\end{array}$ & 56,179 & 0.054 & 0.069 & 0.00 & 0.453 \\
\hline World imports & 56,179 & 0.057 & 0.074 & 0.00 & 0.519 \\
\hline $\begin{array}{l}\text { Real exchange } \\
\text { rate }\end{array}$ & 56,179 & 0.076 & 0.094 & 0.00 & 0.595 \\
\hline $\begin{array}{l}\text { Raw material } \\
\text { prices }\end{array}$ & 56,179 & 0.053 & 0.073 & 0.00 & 0.579 \\
\hline $\begin{array}{l}\text { Short-term } \\
\text { interest rate }\end{array}$ & 56,179 & 0.048 & 0.066 & 0.00 & 0.549 \\
\hline Inflation & 56,179 & 0.061 & 0.079 & 0.00 & 0.507 \\
\hline
\end{tabular}




\section{Table 3: Firm Level Response to Macroeconomic Factors}

Panel (a) reports results of cross-section regressions using the first-stage coefficient estimates as the dependent variable. Observations are weighted by the inverse of the first-stage regression standard errors. Panel (b) reports results of regressions of the partial $R^{2} \mathrm{~s}$ of the observed macroeconomic factors. The sectors not captured by the sector dummies are agriculture, energy, and mining. Panel (c) provides the descriptive statistics for these $R^{2} \mathrm{~s}$. All regressions include a full set of legal fixed effects (unreported). The explanatory variables are 0-1-dummy variables. Residuals are adjusted for heteroskedasticity. ***, $* *, *=$ significant at the $1 \%, 5 \%, 10 \%$-level.

\section{(a) Dependent variable: Coefficient estimates}

\begin{tabular}{l|r|r|r|r|r|r}
\hline \hline & $\begin{array}{c}\text { Domestic } \\
\text { absorption }\end{array}$ & $\begin{array}{c}\text { World } \\
\text { import } \\
\text { demand }\end{array}$ & $\begin{array}{c}\text { Real } \\
\text { exchange } \\
\text { rate }\end{array}$ & $\begin{array}{c}\text { Raw } \\
\text { material } \\
\text { prices }\end{array}$ & $\begin{array}{c}\text { Short-term } \\
\text { interest rate }\end{array}$ & Inflation \\
\hline Large (0/1) & $0.233^{*}$ & $0.055^{* *}$ & $0.105^{* *}$ & $0.018^{* *}$ & $0.220^{* *}$ & $-0.302^{*}$ \\
& $(1.67)$ & $(2.45)$ & $(2.06)$ & $(2.26)$ & $(2.23)$ & $(1.89)$ \\
Listed (0/1) & 0.421 & -0.004 & -0.111 & 0.012 & $0.629^{*}$ & -0.828 \\
& $(0.84)$ & $(0.04)$ & $(0.51)$ & $(0.30)$ & $(1.73)$ & $(1.23)$ \\
Manufacturing (0/1) & -0.277 & $0.105^{* *}$ & -0.005 & $-0.037^{*}$ & $-0.639^{* * *}$ & $1.235^{* * *}$ \\
& $(0.77)$ & $(2.55)$ & $(0.04)$ & $(1.88)$ & $(2.91)$ & $(4.62)$ \\
Services (0/1) & -0.569 & 0.029 & 0.029 & $-0.071^{* * *}$ & $-0.520^{* *}$ & $0.856^{* * *}$ \\
& $(1.50)$ & $(0.64)$ & $(0.21)$ & $(3.39)$ & $(2.24)$ & $(2.92)$ \\
Construction (0/1) & 1.048 & $0.195^{*}$ & 0.029 & -0.034 & $-1.303^{* * *}$ & $3.016^{* * *}$ \\
Constant & $(1.41)$ & $(1.84)$ & $(0.12)$ & $(0.79)$ & $(2.88)$ & $(4.15)$ \\
& -0.075 & -0.095 & -0.045 & 0.023 & 0.071 & -0.212 \\
& $(0.13)$ & $(0.86)$ & $(0.19)$ & $(0.52)$ & $(0.18)$ & $(0.31)$ \\
\hline Observations & 1,446 & 1,446 & 1,446 & 1,446 & 1,446 & 1,446 \\
R-squared & 0.02 & 0.02 & 0.01 & 0.03 & 0.02 & 0.03 \\
\hline \hline
\end{tabular}


(b) Dependent variable: Partial $R^{2}$

\begin{tabular}{|c|c|c|c|c|c|c|}
\hline & $\begin{array}{c}\text { Domestic } \\
\text { absorption }\end{array}$ & $\begin{array}{l}\text { World } \\
\text { import } \\
\text { demand }\end{array}$ & $\begin{array}{l}\text { Real } \\
\text { exchange } \\
\text { rate }\end{array}$ & $\begin{array}{c}\text { Raw } \\
\text { material } \\
\text { prices }\end{array}$ & $\begin{array}{c}\text { Short-term } \\
\text { interest rate }\end{array}$ & Inflation \\
\hline Large $(0 / 1)$ & $\begin{array}{l}-0.002 \\
(0.43)\end{array}$ & $\begin{array}{r}-0.004 \\
(1.21)\end{array}$ & $\begin{array}{l}0.003 \\
(0.58)\end{array}$ & $\begin{array}{l}0.007 \\
(1.52)\end{array}$ & $\begin{array}{l}0.003 \\
(0.78)\end{array}$ & $\begin{array}{r}0.007 * * \\
(1.97)\end{array}$ \\
\hline Listed (0/1) & $\begin{array}{r}-0.01 \\
(0.44)\end{array}$ & $\begin{array}{l}-0.004 \\
(0.26)\end{array}$ & $\begin{array}{c}0.011 \\
(0.57)\end{array}$ & $\begin{array}{l}0.007 \\
(0.53)\end{array}$ & $\begin{array}{c}-0.024 \\
(1.43)\end{array}$ & $\begin{array}{l}-0.01 \\
(0.58)\end{array}$ \\
\hline Manufacturing (0/1) & $\begin{array}{r}-0.018^{*} \\
(1.93)\end{array}$ & $\begin{array}{r}0.025^{* * *} \\
(4.12)\end{array}$ & $\begin{array}{r}-0.006 \\
(0.46)\end{array}$ & $\begin{array}{r}-0.003 \\
(0.23)\end{array}$ & $\begin{array}{r}-0.006 \\
(0.78)\end{array}$ & $\begin{array}{r}0.022 * * * \\
(3.74)\end{array}$ \\
\hline Services (0/1) & $\begin{array}{l}-0.012 \\
(1.29)\end{array}$ & $\begin{array}{r}0.027^{* * *} \\
(4.18)\end{array}$ & $\begin{array}{l}0.008 \\
(0.52)\end{array}$ & $\begin{array}{r}-0.004 \\
(0.27)\end{array}$ & $\begin{array}{r}-0.011 \\
(1.31)\end{array}$ & $\begin{array}{r}0.017^{* * *} \\
(2.74)\end{array}$ \\
\hline Construction (0/1) & $\begin{array}{r}-0.028^{* *} \\
(2.55)\end{array}$ & $\begin{array}{r}0.009 \\
(0.84)\end{array}$ & $\begin{array}{r}-0.037^{* *} \\
(2.20)\end{array}$ & $\begin{array}{l}-0.021 \\
(1.25)\end{array}$ & $\begin{array}{r}-0.021^{* *} \\
(2.28)\end{array}$ & $\begin{array}{r}0.020^{* *} \\
(2.15)\end{array}$ \\
\hline Constant & $\begin{array}{r}0.073 * * * \\
(2.98) \\
\end{array}$ & $\begin{array}{r}0.036^{* *} \\
(2.50)\end{array}$ & $\begin{array}{r}0.057 * * * \\
(2.73)\end{array}$ & $\begin{array}{r}0.047 * * * \\
(2.70)\end{array}$ & $\begin{array}{r}0.070^{* * *} \\
(3.97) \\
\end{array}$ & $\begin{array}{r}0.037 * * \\
(2.31)\end{array}$ \\
\hline Observations & 1,446 & 1,446 & 1,446 & 1,446 & 1,446 & 1,446 \\
\hline R-squared & 0.01 & 0.01 & 0.01 & 0.01 & 0.01 & 0.01 \\
\hline
\end{tabular}


Table 4: Determinants of Firm level Volatility of Real Sales

This table reports results of panel fixed effects regressions. The dependent variable is the squared residual of a regression of firm level real sales growth on macroeconomic factors. Asset growth, the inventorysales ratio, and leverage are residuals of first-stage regressions as well. "Year" is a linear time trend, "Unification" dummy is a dummy variable which is set to "One" for the years 1991-1995 and "Zero" otherwise. ${ }^{* * *}, * *, *=$ significant at the $1 \%, 5 \%, 10 \%$-level.

(a) Baseline Regressions and sample splits by type of firm

\begin{tabular}{|c|c|c|c|c|c|c|c|}
\hline & $\begin{array}{c}\text { Full } \\
\text { sample }\end{array}$ & $\begin{array}{c}\text { Manu- } \\
\text { facturing }\end{array}$ & Services & Listed & Unlisted & Small & Large \\
\hline Asset growth & $\begin{array}{r}0.036^{* * *} \\
(6.01)\end{array}$ & $\begin{array}{r}0.028 * * * \\
(3.32)\end{array}$ & $\begin{array}{r}0.045 * * * \\
(5.16)\end{array}$ & $\begin{array}{r}0.110^{* * *} \\
(2.66)\end{array}$ & $\begin{array}{r}0.028 * * * \\
(5.70)\end{array}$ & $\begin{array}{r}0.027^{* * * *} \\
(4.28)\end{array}$ & $\begin{array}{r}0.048 * * * \\
(4.34)\end{array}$ \\
\hline Asset growth (t-1) & $\begin{array}{r}0.016^{* * *} \\
(4.82)\end{array}$ & $\begin{array}{r}0.014^{* * *} \\
(3.03)\end{array}$ & $\begin{array}{r}0.011 * * * \\
(2.78)\end{array}$ & $\begin{array}{r}0.040^{* * *} \\
(2.70)\end{array}$ & $\begin{array}{r}0.013 * * * \\
(4.08)\end{array}$ & $\begin{array}{r}0.012^{* * *} \\
(3.45)\end{array}$ & $\begin{array}{r}0.021^{* * *} \\
(3.47)\end{array}$ \\
\hline Asset growth (t-2) & $\begin{array}{l}0.002 \\
(0.62)\end{array}$ & $\begin{array}{r}0.002 \\
(0.36)\end{array}$ & $\begin{array}{l}0.003 \\
(1.02)\end{array}$ & $\begin{array}{l}0.024 \\
(1.37)\end{array}$ & $\begin{array}{r}0.00 \\
(0.16)\end{array}$ & $\begin{array}{l}0.002 \\
(0.86)\end{array}$ & $\begin{array}{l}0.001 \\
(0.22)\end{array}$ \\
\hline Asset growth (t-3) & $\begin{array}{r}-0.002 \\
(0.99)\end{array}$ & $\begin{array}{r}-0.004 \\
(1.17)\end{array}$ & $\begin{array}{l}0.004 \\
(1.45)\end{array}$ & $\begin{array}{r}0.00 \\
(0.03)\end{array}$ & $\begin{array}{r}-0.002 \\
(1.25)\end{array}$ & $\begin{array}{r}-0.003 \\
(0.94)\end{array}$ & $\begin{array}{r}-0.002 \\
(0.56)\end{array}$ \\
\hline Inventory-sales ratio & $\begin{array}{r}-0.073 * * * \\
(3.76)\end{array}$ & $\begin{array}{r}-0.061^{* *} \\
(1.98)\end{array}$ & $\begin{array}{r}-0.072^{* * *} \\
(3.34)\end{array}$ & $\begin{array}{r}-0.062 \\
(1.30)\end{array}$ & $\begin{array}{r}-0.075^{* * *} \\
(3.54)\end{array}$ & $\begin{array}{r}-0.071^{* * *} \\
(3.90)\end{array}$ & $\begin{array}{r}-0.076^{* *} \\
(2.42)\end{array}$ \\
\hline Leverage & $\begin{array}{r}0.00 \\
(0.74)\end{array}$ & $\begin{array}{r}0.00 \\
(0.54)\end{array}$ & $\begin{array}{r}0.00 \\
(0.34)\end{array}$ & $\begin{array}{r}0.00 \\
(0.41)\end{array}$ & $\begin{array}{r}0.00 \\
(0.48)\end{array}$ & $\begin{array}{r}0.00 \\
(0.78)\end{array}$ & $\begin{array}{r}0.00 \\
(0.17)\end{array}$ \\
\hline Unification & $\begin{array}{r}0.00 \\
(0.31)\end{array}$ & $\begin{array}{r}0.00 \\
(0.11)\end{array}$ & $\begin{array}{r}0.00 \\
(0.08)\end{array}$ & $\begin{array}{r}-0.003^{*} \\
(1.79)\end{array}$ & $\begin{array}{l}0.001 \\
(0.78)\end{array}$ & $\begin{array}{r}0.00 \\
(0.10)\end{array}$ & $\begin{array}{r}0.00 \\
(0.29)\end{array}$ \\
\hline Year & $\begin{array}{r}0.000 * * \\
(2.05)\end{array}$ & $\begin{array}{r}0.00 \\
(1.12)\end{array}$ & $\begin{array}{r}0.00 \\
(1.15)\end{array}$ & $\begin{array}{r}0.000 * * \\
(2.46)\end{array}$ & $\begin{array}{r}0.00 \\
(1.20)\end{array}$ & $\begin{array}{r}0.00 \\
(0.55)\end{array}$ & $\begin{array}{r}0.000^{* *} \\
(1.96)\end{array}$ \\
\hline Constant & $\begin{array}{r}-0.142^{* *} \\
(2.13) \\
\end{array}$ & $\begin{array}{r}-0.032 \\
(0.43) \\
\end{array}$ & $\begin{array}{r}-0.109 \\
(1.11) \\
\end{array}$ & $\begin{array}{r}-0.673^{* *} \\
(2.59) \\
\end{array}$ & $\begin{array}{r}-0.067 \\
(1.06) \\
\end{array}$ & $\begin{array}{l}0.015 \\
(0.20) \\
\end{array}$ & $\begin{array}{r}-0.145 \\
(1.34) \\
\end{array}$ \\
\hline Sector dummies & yes & yes & yes & yes & yes & yes & yes \\
\hline Legal dummies & yes & yes & yes & yes & yes & yes & yes \\
\hline Year dummies & no & no & no & no & no & no & no \\
\hline Observations & 43,799 & 25,291 & 15,550 & 4,857 & 38,942 & 21,930 & 21,869 \\
\hline Number of cross-sections & 1,464 & 884 & 579 & 212 & 1337 & 731 & 733 \\
\hline R-squared & 0.02 & 0.01 & 0.03 & 0.06 & 0.02 & 0.02 & 0.02 \\
\hline
\end{tabular}


(b) Sample splits by time

\begin{tabular}{lr|r|r|r|r|r}
\hline \hline & \multicolumn{1}{c|}{$1970 \mathrm{~s}$} & \multicolumn{1}{c}{$1980 \mathrm{~s}$} & \multicolumn{1}{c}{$1990 \mathrm{~s}$} & \multicolumn{1}{c}{$2000 \mathrm{~s}$} & Pre-1985 & Post-1985 \\
\hline Asset growth & 0.001 & $0.033^{* * *}$ & $0.050^{* * *}$ & $0.049^{* * *}$ & $0.018^{* *}$ & $0.045^{* * *}$ \\
& $(0.08)$ & $(2.77)$ & $(4.35)$ & $(4.07)$ & $(2.15)$ & $(5.74)$ \\
Asset growth (t-1) & 0.012 & $0.027^{* * *}$ & $0.016^{* * *}$ & $0.009^{*}$ & $0.025^{* * *}$ & $0.014^{* * *}$ \\
& $(1.39)$ & $(3.76)$ & $(2.69)$ & $(1.80)$ & $(3.78)$ & $(3.73)$ \\
Asset growth (t-2) & 0.002 & 0.003 & 0.004 & 0.005 & 0.003 & 0.002 \\
& $(0.25)$ & $(0.43)$ & $(0.76)$ & $(1.00)$ & $(0.84)$ & $(0.67)$ \\
Asset growth (t-3) & -0.002 & -0.002 & -0.002 & 0.00 & -0.004 & -0.001 \\
& $(0.46)$ & $(0.31)$ & $(0.37)$ & $(0.06)$ & $(0.91)$ & $(0.45)$ \\
Inventory-sales ratio & -0.002 & $-0.085^{* *}$ & -0.125 & -0.048 & $-0.089^{* *}$ & $-0.080^{*}$ \\
& $(0.09)$ & $(2.21)$ & $(1.63)$ & $(0.85)$ & $(2.05)$ & $(1.88)$ \\
Leverage & 0.00 & 0.00 & 0.00 & 0.00 & 0.00 & 0.00 \\
& $(0.30)$ & $(0.51)$ & $(0.21)$ & $(1.54)$ & $(0.37)$ & $(0.47)$ \\
Unification & & & $0.005^{* * *}$ & & & 0.00 \\
& & & $(3.80)$ & & & $(0.34)$ \\
Year & $0.001^{* * *}$ & 0.00 & $0.001^{* * *}$ & $0.001^{* *}$ & $0.001^{* * *}$ & 0.00 \\
& $(3.79)$ & $(0.30)$ & $(4.15)$ & $(2.12)$ & $(3.13)$ & $(1.28)$ \\
Constant & $-2.002 * * *$ & -0.102 & $-1.710^{* * *}$ & $-1.122^{* *}$ & $-1.135^{* * *}$ & -0.128 \\
& $(3.73)$ & $(0.29)$ & $(4.15)$ & $(2.01)$ & $(3.11)$ & $(1.18)$ \\
\hline Sector dummies & yes & yes & yes & yes & yes & yes \\
Legal dummies & yes & yes & yes & yes & yes & yes \\
Year dummies & no & no & no & no & no & no \\
\hline Observations & 7,088 & 14,245 & 14,097 & 8,369 & 14,221 & 29,578 \\
Number of cross-sections & 1,459 & 1,461 & 1,461 & 1,453 & 1,462 & 1,464 \\
R-squared & 0.02 & 0.03 & 0.05 & 0.03 & 0.02 & 0.03 \\
\hline \hline
\end{tabular}




\section{Table 5: Regression Results Heteroskedastic Regression Model}

This table reports results of the heteroskedastic regression model proposed by Harvey (1976). The dependent variable is the mean firm level volatility of sales for firms in each sector. Year is a linear time trend, Unification dummy is a dummy variable which is set to "One” for the years 1991-1995 and "Zero" otherwise. ***, **, * significant at the $1 \%, 5 \%, 10 \%$-level.

\begin{tabular}{|c|c|c|}
\hline & (1) & $(2)$ \\
\hline \multicolumn{3}{|l|}{ Mean equation } \\
\hline Asset growth $(t)$ & $\begin{array}{c}0.32 * * * \\
(51.24)\end{array}$ & \\
\hline Asset growth $(t-1)$ & $\begin{array}{c}0.09 * * * \\
(18.55)\end{array}$ & \\
\hline Asset growth $(t-2)$ & $\begin{array}{c}-0.02 * * * \\
(-3.53)\end{array}$ & \\
\hline Listed (0/1) & $\begin{array}{c}-0.0004 \\
(-0.26)\end{array}$ & \\
\hline Inventory-sales ratio (\%) & $\begin{array}{c}-0.46 * * * \\
(-11.52)\end{array}$ & \\
\hline Leverage & $\begin{array}{l}-0.00 \\
(-0.98)\end{array}$ & \\
\hline Large $(0 / 1)$ & $\begin{array}{l}0.001 \\
(1.22)\end{array}$ & \\
\hline Manufacturing (0/1) & $\begin{array}{l}-0.001 \\
(-0.57)\end{array}$ & \\
\hline Services (0/1) & $\begin{array}{l}-0.001 \\
(-0.39)\end{array}$ & \\
\hline Construction $(0 / 1)$ & $\begin{array}{l}0.005 \\
(0.73)\end{array}$ & \\
\hline Year & $\begin{array}{c}-0.00 \\
(-0.08)\end{array}$ & $\begin{array}{c}-0.00 \\
(-0.69)\end{array}$ \\
\hline Unification (0/1) & $\begin{array}{l}-0.001 \\
(-0.08)\end{array}$ & $\begin{array}{c}0.00 \\
(0.09) \\
\end{array}$ \\
\hline Variance equation & & \\
\hline Asset growth $(t)$ & $\begin{array}{c}0.86 * * * \\
(8.22)\end{array}$ & $\begin{array}{c}1.01 * * * \\
(9.32)\end{array}$ \\
\hline Asset growth $(t-1)$ & $\begin{array}{c}0.57 * * * \\
(5.38)\end{array}$ & $\begin{array}{c}0.50 * * * \\
(4.64)\end{array}$ \\
\hline Asset growth $(t-2)$ & $\begin{array}{c}0.15 \\
(1.44)\end{array}$ & $\begin{array}{c}0.08 \\
(0.78)\end{array}$ \\
\hline Listed (0/1) & $\begin{array}{c}0.13^{* *} \\
(2.17)\end{array}$ & $\begin{array}{c}0.08 \\
(1.42)\end{array}$ \\
\hline Inventory-sales ratio (\%) & $\begin{array}{c}0.23 \\
(1.03)\end{array}$ & $\begin{array}{c}-0.95 * * * \\
(-4.66)\end{array}$ \\
\hline Leverage & & \\
\hline Large $(0 / 1)$ & $\begin{array}{c}-0.18 * * * \\
(-5.77)\end{array}$ & $\begin{array}{c}-0.14 * * * \\
(-5.10)\end{array}$ \\
\hline Manufacturing (0/1) & $\begin{array}{c}-0.03 \\
(-0.42)\end{array}$ & $\begin{array}{c}-0.02 \\
(-0.30)\end{array}$ \\
\hline Services (0/1) & $\begin{array}{l}0.001 \\
(0.01)\end{array}$ & $\begin{array}{c}0.04 \\
(0.49)\end{array}$ \\
\hline Construction $(0 / 1)$ & $\begin{array}{l}1.32 * * * \\
(11.52)\end{array}$ & $\begin{array}{l}1.25 * * * \\
(11.75)\end{array}$ \\
\hline Year & $\begin{array}{l}0.001 \\
(0.97)\end{array}$ & $\begin{array}{c}0.003^{*} \\
(1.98)\end{array}$ \\
\hline Unification & $\begin{array}{c}-0.05 \\
(-0.90)\end{array}$ & $\begin{array}{c}-0.04 \\
(-0.85)\end{array}$ \\
\hline
\end{tabular}




\section{Graph 1: Unconditional Firm level Versus Aggregated Volatility}

Unconditional firm level output volatility is the median volatility of firm level sales growth over a fiveyear window. Aggregated output volatility is the corresponding volatility of GDP growth.

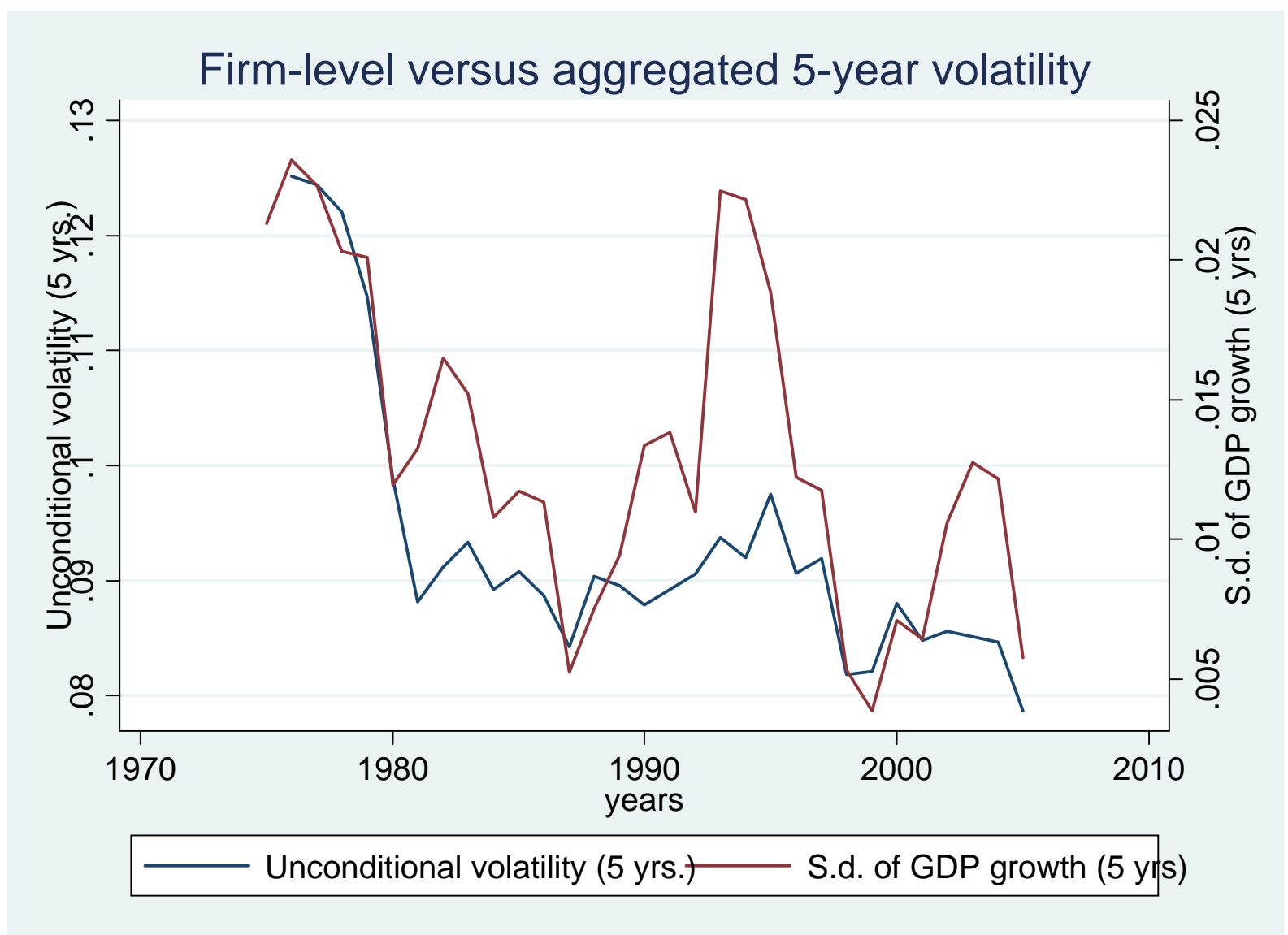




\section{Graph 2: Conditional Versus Unconditional Firm Level Volatility}

Unconditional firm level output volatility is the median volatility of firm level sales growth over a fiveyear window. Conditional firm level output volatility is the corresponding volatility of the residual sales growth using the method proposed by Pesaran (2006) to control for macroeconomic developments.

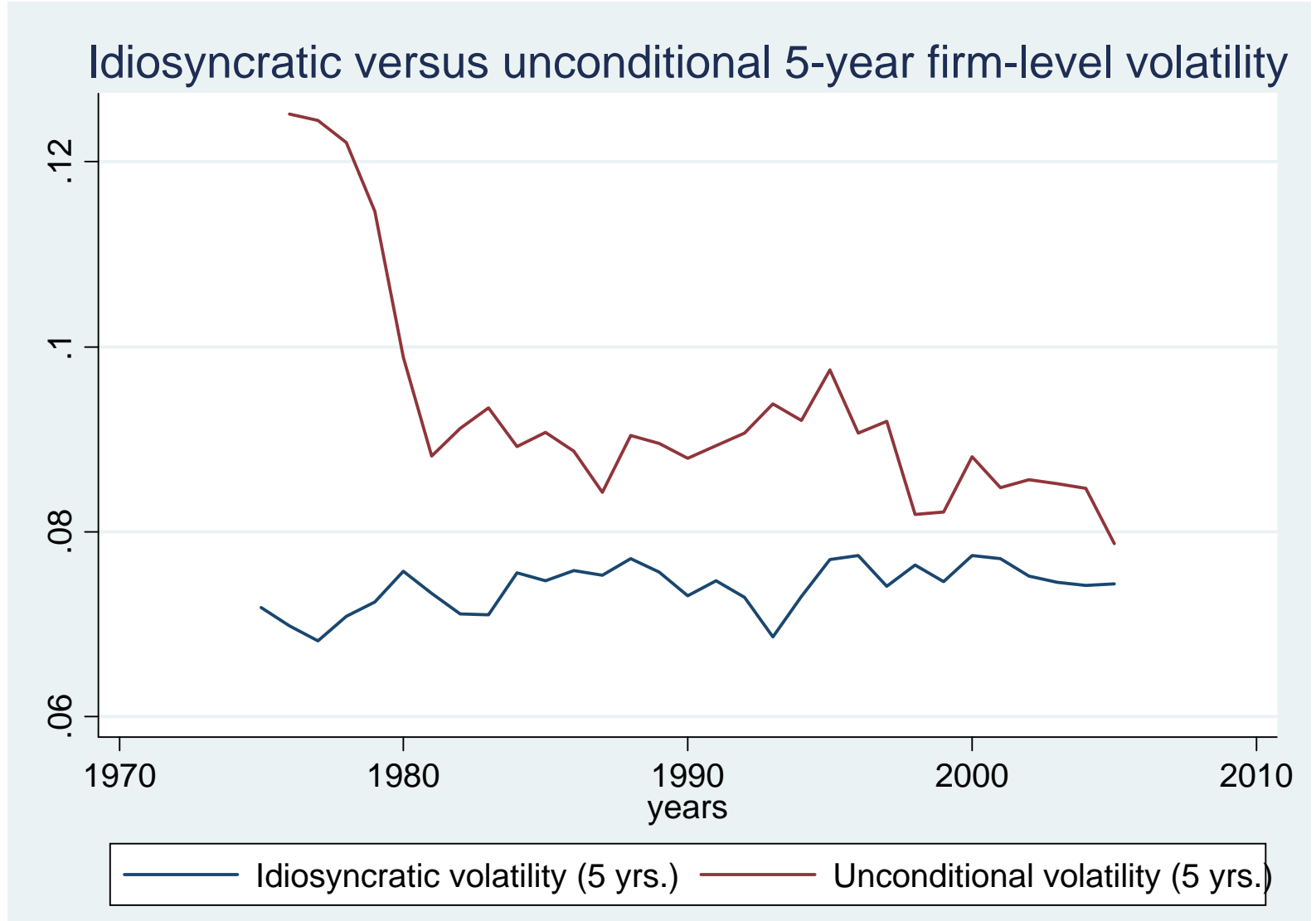




\section{CESifo Working Paper Series}

for full list see www.cesifo-group.org/wp

(address: Poschingerstr. 5, 81679 Munich, Germany, office@cesifo.de)

2261 J. Atsu Amegashie and Marco Runkel, The Paradoxes of Revenge in Conflicts, March 2008

2262 Hans Jarle Kind, Marko Koethenbuerger and Guttorm Schjelderup, Efficiency Enhancing Taxation in Two-sided Markets, March 2008

2263 M. Hashem Pesaran, Til Schuermann and L. Vanessa Smith, Forecasting Economic and Financial Variables with Global VARs, March 2008

2264 Volker Grossmann, Entrepreneurial Innovation and Sustained Long-run Growth without Weak or Strong Scale Effects, March 2008

2265 Robert S. Chirinko and Huntley Schaller, The Irreversibility Premium, March 2008

2266 Andrea Galeotti and José Luis Moraga-González, Platform Intermediation in a Market for Differentiated Products, April 2008

2267 Torben M. Andersen and Michael Svarer, The Role of Workfare in Striking a Balance between Incentives and Insurance in the Labour Market, April 2008

2268 Harald Badinger, Cyclical Fiscal Policy, Output Volatility, and Economic Growth, April 2008

2269 Thomas Aronsson and Erkki Koskela, Outsourcing and Optimal Nonlinear Taxation: A Note, April 2008

2270 Gary E. Bolton, Claudia Loebbecke and Axel Ockenfels, How Social Reputation Networks Interact with Competition in Anonymous Online Trading: An Experimental Study, April 2008

2271 Nikolaus Wolf, Scylla and Charybdis. Explaining Europe’s Exit from Gold, January 1928 - December 1936, April 2008

2272 Michael Funke and Marc Gronwald, The Undisclosed Renminbi Basket: Are the Markets Telling us something about where the Renminbi - US Dollar Exchange Rate is Going?, April 2008

2273 Thor Olav Thoresen and Annette Alstadsæter, Shifts in Organizational Form under a Dual Income Tax System, April 2008

2274 Helge Berger and Volker Nitsch, Too many Cooks? Committees in Monetary Policy, April 2008

2275 Yin-Wong Cheung and Eiji Fujii, Deviations from the Law of One Price in Japan, April 2008 
2276 Michael S. Michael, Sajal Lahiri and Panos Hatzipanayotou, Integrated Reforms of Indirect Taxes in the Presence of Pollution, April 2008

2277 Bas Jacobs, Is Prescott Right? Welfare State Policies and the Incentives to Work, Learn and Retire, April 2008

2278 Burkhard Heer and Alfred Maußner, Value Function Iteration as a Solution Method for the Ramsey Model, April 2008

2279 Jarko Fidrmuc and Christa Hainz, Integrating with their Feet: Cross-Border Lending at the German-Austrian Border, April 2008

2280 Kristof Dascher and Alexander Haupt, The Political Economy of Regional Integration Projects at Borders where Rich and Poor Meet: The Role of Cross-Border Shopping and Community Sorting, April 2008

2281 Katrin Assenmacher-Wesche and M. Hashem Pesaran, A VECX* Model of the Swiss Economy, April 2008

2282 Christophe Rault, Robert Sova and Ana Maria Sova, Modeling International Trade Flows between CEEC and OECD Countries, April 2008

2283 Timo Boppart, Josef Falkinger, Volker Grossmann, Ulrich Woitek and Gabriela Wüthrich, Qualifying Religion: The Role of Plural Identities for Educational Production, April 2008

2284 Armin Falk, David Huffman and W. Bentley MacLeod, Institutions and Contract Enforcement, April 2008

2285 Axel Dreher and Stefan Voigt, Does Membership in International Organizations Increase Governments' Credibility? Testing the Effects of Delegating Powers, April 2008

2286 Xavier Freixas and Bruno M. Parigi, Lender of Last Resort and Bank Closure Policy, April 2008

2287 Regina Dionisius, Samuel Muehlemann, Harald Pfeifer, Günter Walden, Felix Wenzelmann and Stefan C. Wolter, Cost and Benefit of Apprenticeship Training - A Comparison of Germany and Switzerland, April 2008

2288 Francesco Daveri and Cecilia Jona-Lasinio, Off-Shoring and Productivity Growth in the Italian Manufacturing Industries, April 2008

2289 Mikael Priks, Do Surveillance Cameras Affect Unruly Behavior? A Close Look at Grandstands, April 2008

2290 Marianna Belloc and Daniela Federici, A Two-Country NATREX Model for the Euro/Dollar, April 2008

2291 Nicolas Treich, The Value of a Statistical Life under Ambiguity Aversion, April 2008 
2292 J. Atsu Amegashie, Socially-Tolerable Discrimination, April 2008

2293 M. Hashem Pesaran and Andreas Pick, Forecasting Random Walks Under Drift Instability, April 2008

2294 Steven Brakman, Gus Garita, Harry Garretsen and Charles van Marrewijk, Unlocking the Value of Cross-Border Mergers and Acquisitions, May 2008

2295 Eric O’N. Fisher and Kathryn G. Marshall, The Structure of the American Economy, May 2008

2296 Claudia M. Buch and Martin Schlotter, Regional Origins of Employment Volatility: Evidence from German States, May 2008

2297 Helmuth Cremer, Philippe De Donder, Dario Maldonado and Pierre Pestieau, Taxing Sin Goods and Subsidizing Health Care, May 2008

2298 Reinhilde Veugelers and Frederick van der Ploeg, Reforming European Universities: Scope for an Evidence-Based Process, May 2008

2299 Jon H. Fiva and Lars J. Kirkebøen, Does the Housing Market React to New Information on School Quality?, May 2008

2300 Tina Klautke and Alfons J. Weichenrieder, Interest Income Tax Evasion, the EU Savings Directive, and Capital Market Effects, May 2008

2301 Harald Badinger and Peter Egger, GM Estimation of Higher Order Spatial Autoregressive Processes in Panel Data Error Component Models, May 2008

2302 Jan K. Brueckner, Slot-Based Approaches to Airport Congestion Management, May 2008

2303 Sören Blomquist, Vidar Christiansen and Luca Micheletto, Public Provision of Private Goods and Nondistortionary Marginal Tax Rates, May 2008

2304 Dan Anderberg and Alessandro Balestrino, The Political Economy of Post-Compulsory Education Policy with Endogenous Credit Constraints, May 2008

2305 Tomer Blumkin, Yoram Margalioth and Efraim Sadka, The Role of Stigma in the Design of Welfare Programs, May 2008

2306 Vesa Kanniainen and Paolo M. Panteghini, Tax Neutrality: Illusion or Reality? The Case of Entrepreneurship, May 2008

2307 Thomas Dohmen, Armin Falk, David Huffman and Uwe Sunde, The Intergenerational Transmission of Risk and Trust Attitudes, May 2008

2308 Guglielmo Maria Caporale and Mario Cerrato, Using Chebyshev Polynomials to Approximate Partial Differential Equations, May 2008 
2309 Peter Egger and Doina Maria Radulescu, Labour Taxation and Foreign Direct Investment, May 2008

2310 Laurent Linnemer, Dissipative Advertising Signals Quality even without Repeat Purchases, May 2008

2311 Jordi Jofre-Monseny and Albert Solé-Ollé, Which Communities should be afraid of Mobility? The Effects of Agglomeration Economies on the Sensitivity of Firm Location to Local Taxes, May 2008

2312 Andreas Haufler and Ferdinand Mittermaier, Unionisation Triggers Tax Incentives to Attract Foreign Direct Investment, May 2008

2313 Ronel Elul and Piero Gottardi, Bankruptcy: Is it enough to Forgive or must we also Forget?, May 2008

2314 Andreas Irmen and Johanna Kuehnel, Productive Government Expenditure and Economic Growth, May 2008

2315 Beate Henschel, Carsten Pohl and Marcel Thum, Demographic Change and Regional Labour Markets: The Case of Eastern Germany, May 2008

2316 Gabriel Felbermayr, Wido Geis and Wilhelm Kohler, Restrictive Immigration Policy in Germany: Pains and Gains Foregone?, May 2008

2317 Michael Hofmann, Gerhard Kempkes and Helmut Seitz, Demographic Change and Public Sector Budgets in a Federal System, May 2008

2318 Paul De Grauwe, Macroeconomic Modeling when Agents are Imperfectly Informed, June 2008

2319 Johann K. Brunner and Susanne Pech, Optimum Taxation of Inheritances, June 2008

2320 Thomas Eichner and Marco Runkel, Corporate Income Taxation of Multinationals in a General Equilibrium Model, June 2008

2321 Rainald Borck and Matthias Wrede, Subsidies for Intracity and Intercity Commuting, June 2008

2322 Patricia Apps and Ray Rees, Testing the Pareto Efficiency of Household Resource Allocations, June 2008

2323 Amihai Glazer, Vesa Kanniainen and Panu Poutvaara, Firms' Ethics, Consumer Boycotts, and Signalling, June 2008

2324 Claudia M. Buch, Jörg Döpke and Kerstin Stahn, Great Moderation at the Firm Level? Unconditional vs. Conditional Output Volatility, June 2008 